Article

\title{
Amethyst Occurrences in Tertiary Volcanic Rocks of Greece: Mineralogical, Fluid Inclusion and Oxygen Isotope Constraints on Their Genesis
}

\author{
Panagiotis Voudouris ${ }^{1, *}$, Vasilios Melfos ${ }^{2}{ }^{(\mathbb{D}}$, Constantinos Mavrogonatos ${ }^{1}{ }^{(\mathbb{C}}$, Alexandre Tarantola $^{3}$, \\ Jens Götze ${ }^{4}$, Dimitrios Alfieris ${ }^{5}$, Victoria Maneta ${ }^{6}$ and Ioannis Psimis ${ }^{7}$ \\ 1 Faculty of Geology and Geoenvironment, National and Kapodistrian University of Athens, 15784 Athens, \\ Greece; kmavrogon@geol.uoa.gr \\ 2 Faculty of Geology, Aristotle University of Thessaloniki, 54124 Thessaloniki, Greece; melfosv@geo.auth.gr \\ 3 GeoRessources, Faculté des Sciences et Technologies, UMR Université de Lorraine, 54506 Nancy, France; \\ alexandre.tarantola@univ-lorraine.fr \\ 4 Institute of Mineralogy, TU Bergakademie Freiberg, 09599 Freiberg, Germany; jens.goetze@mineral.tu-freiberg.de \\ 56 Kairi str., 15126 Athens, Greece; dimitrisal@hotmail.com \\ 6 Department of Earth Sciences, St. Francis Xavier University, 5005 Chapel Square, Antigonish, NS B2G 2W5, \\ Canada; victoria.maneta@gmail.com \\ 7 Maccaferri Hellas Ltd., 13674 Athens, Greece; giannis.psimis@gmail.com \\ * Correspondence: voudouris@geol.uoa.gr; Tel.: +30-21-0727-4129
}

Received: 19 June 2018; Accepted: 25 July 2018; Published: 28 July 2018

check for updates

\begin{abstract}
Epithermally altered volcanic rocks in Greece host amethyst-bearing veins in association with various silicates, carbonates, oxides and sulfides. Host rocks are Oligocene to Pleistocene calc-alkaline to shoshonitic lavas and pyroclastics of intermediate to acidic composition. The veins are integral parts of high to intermediate sulfidation epithermal mineralized centers in northern Greece (e.g., Kassiteres-Sapes, Kirki, Kornofolia/Soufli, Lesvos Island) and on Milos Island. Colloform-crustiform banding with alternations of amethyst, chalcedony and/or carbonates is a common characteristic of the studied amethyst-bearing veins. Hydrothermal alteration around the quartz veins includes sericitic, K-feldspar (adularia), propylitic and zeolitic types. Precipitation of amethyst took place from near-neutral to alkaline fluids, as indicated by the presence of various amounts of gangue adularia, calcite, zeolites, chlorite and smectite. Fluid inclusion data suggest that the studied amethyst was formed by hydrothermal fluids with relatively low temperatures $\left(\sim 200-250{ }^{\circ} \mathrm{C}\right)$ and low to moderate salinity (1-8 wt \% NaCl equiv). A fluid cooling gradually from the external to the inner parts of the veins, possibly with subsequent boiling in an open system, is considered for the amethysts of Silver Hill in Sapes and Kassiteres. Amethysts from Kornofolia, Megala Therma, Kalogries and Chondro Vouno were formed by mixing of moderately saline hydrothermal fluids with low-salinity fluids at relatively lower temperatures indicating the presence of dilution processes and probably boiling in an open system. Stable isotope data point to mixing between magmatic and marine (and/or meteoric) waters and are consistent with the oxidizing conditions required for amethyst formation.
\end{abstract}

Keywords: amethyst; volcanic rock; hydrothermal alteration; gemstones

\section{Introduction}

Amethyst is a quartz variety often used in jewellery and occurs in varying shades of violet colors [1,2]. Its name comes from the ancient Greek words "a" (not) and "methystos" (intoxicated), a reference to the belief that the stone protected its owner from drunkenness. The colors of amethyst 
range from bluish violet to purple-violet and red-violet and its origin has been controversial for a long time [2-6]. According to Cox [3] as cited also in Fritsch and Rossman [4] the purple color in amethyst is due to $\mathrm{O}^{2-} \rightarrow \mathrm{Fe}^{4+}$ inter valence charge transfer, which absorbs light in the middle of the visible region. The $\mathrm{Fe}^{4+}$ ion, at the $\mathrm{Fe}^{4+}$ site (e.g., $\left.\mathrm{FeO}_{4}\right)$ is formed from $\mathrm{Fe}^{3+}$ by the action of ionizing radiation and is important for the coloration of amethyst [2]. However, is remains controversial if the $\mathrm{Fe}^{4+}$ site is substitutional, e.g., [3], or interstitial [5].

Brazil is the main amethyst producer today, counting more than ten very important deposits $[1,6]$. Other amethyst producing countries are Mexico, Uruguay, Canada, South Korea, Russia, Zambia, Sri Lanka and India, but the best varieties of amethysts have been extracted from the central Ural mountains $[1,7,8]$.

Amethyst is formed in igneous, metamorphic and sedimentary rocks as well as in hydrothermal veins, metasomatic and hot spring deposits $[1,9,10]$. Well-formed crystals occur as filling druses in various igneous rocks, such as granites, or volcanic rocks, mainly lavas. In metamorphic rocks, amethyst is a relatively common mineral in the so-called alpine-type fissures.

Greece includes several areas with major and minor occurrences of amethyst deposits [11-15]. These deposits are associated with magmatic-hydrothermal (e.g., skarns, volcanic rocks) and metamorphic environments of various ages. Amethyst of best quality has been found in well-formed crystals within extensional alpinotype fissures in metamorphic core complexes, which are related to tectonic exhumation of the Rhodope- and Attico-Cycladic massifs [11]. Gem quality amethyst crystals are also found in the skarn of Serifos Island, where amethyst occurs as scepter on prase quartz crystals. However, the above occurrences are of minor importance compared to the occurrences hosted in volcanic rocks, which can also be considered as potential deposits for possible future exploitation.

This study focuses on five amethyst deposits which are related to the Tertiary volcanic rocks of Greece. Three amethyst-bearing areas are located in Northern Greece (Kassiteres-Sapes, Kirki, Kornofolia), while the remaining two occur on Lesvos and Milos Islands in the Aegean Sea. Host rocks for the studied amethyst occurrences are lavas and pyroclastics of calc-alkaline to shoshonitic composition and Oligocene to Pleistocene age. This work summarizes earlier work and presents new geological, mineralogical, microthermometric and oxygen isotope data, which aim to a better understanding of the conditions of amethyst formation in the studied deposits.

\section{Meterials and Methods}

Thirty-five thin and ten thin-and-polished sections of amethyst-bearing veins and host rocks were studied by optical and a JEOL JSM 5600 scanning electron microscope equipped with back-scattered imaging capabilities, respectively, at the Department of Mineralogy and Petrology at the University of Athens (Greece). Quantitative analyses were carried out at the University of Athens, Department of Geology, using a JEOL JSM 5600 scanning electron microscope equipped with automated OXFORD ISIS 300 energy dispersive analysis system. Analytical conditions were $20 \mathrm{kV}$ accelerating voltage, $0.5 \mathrm{nA}$ beam current, $<2 \mu \mathrm{m}$ beam diameter and $60 \mathrm{~s}$ count times. The $\mathrm{X}$-ray lines used were $\mathrm{AlK} \alpha, \operatorname{SiK} \alpha$, $\mathrm{BaL} \alpha, \mathrm{CaK} \alpha, \mathrm{CeL} \alpha, \mathrm{KK} \alpha, \mathrm{FeK} \alpha, \mathrm{NaK} \alpha, \mathrm{TiK} \alpha, \mathrm{PK} \alpha, \mathrm{CrK} \alpha, \mathrm{MnK} \alpha, \mathrm{MgK} \alpha$, and $\operatorname{SrL} \alpha$. The reference substances used were orthoclase, albite, and wollastonite (for $\mathrm{K}, \mathrm{Na}$, Si and $\mathrm{Ca}$ ), pyrite for $\mathrm{Fe}$, and synthetic $\mathrm{Ti}, \mathrm{Cr}, \mathrm{Mn}, \mathrm{MgO}$ and $\mathrm{Al}_{2} \mathrm{O}_{3}$ (for $\mathrm{Ti}, \mathrm{Cr}, \mathrm{Mn}, \mathrm{Mg}$ and $\mathrm{Al}$ ).

Fluid inclusion spatial relationships and phase changes during heating/freezing runs within the inclusions were microscopically observed in a total of 20 doubly polished thin sections from Silver Hill of Sapes, Kassiteres, Kornofolia of Soufli, Kirki, Megala Therma of Lesvos Island and Chondro Vouno and Kalogries of Milos Island. Routine heating and freezing runs were performed with a LINKAM THM-600/TMS 90 stage coupled to a Leitz SM-LUX-POL microscope at the Department of Mineralogy, Petrology and Economic Geology at Aristotle University of Thessaloniki (Greece). Part of the microthermometric studies were carried out at the Institute of Mineralogy-Petrology of Hamburg University (Germany), using a CHAIXMECA heating and freezing stage. Calibration of the stages was achieved using organic reference substances with known melting points and ice $\left(\mathrm{H}_{2} \mathrm{O}\right)$. 
The precision of the measurements was $\pm 0.2{ }^{\circ} \mathrm{C}$ during low-temperature measurements and $\pm 1{ }^{\circ} \mathrm{C}$ during high-temperature measurements. The SoWat program [16] was used to process fluid inclusion data based on equations of Bodnar [17] in the system $\mathrm{H}_{2} \mathrm{O}-\mathrm{NaCl}$.

Stable isotope analyses were performed at the Stable Isotope and Atmospheric Laboratories, Department of Geology, Royal Holloway, University of London (UK). The oxygen isotope composition of quartz was obtained using a $\mathrm{CO}_{2}$ laser fluorination system similar to that described by Mattey [18]. Each mineral separate or standard is weighed at $1.7 \mathrm{mg} \pm 10 \%$. These were loaded into the 16-holes of a nickel sample tray, which was inserted into the reaction chamber and then evacuated. The oxygen was released by a $30 \mathrm{~W}$ Synrad $\mathrm{CO}_{2}$ laser in the presence of $\mathrm{BrF}_{5}$ reagent. The yield of oxygen was measured as a calibrated pressure based on the estimated or known oxygen content of the mineral being analyzed. Low yields result in low $\delta^{18} \mathrm{O}$ values for all mineral phases, so accurate yield calculations are essential. Yields of $>90 \%$ are required for most minerals to give satisfactory $\delta^{18} \mathrm{O}$ values. The oxygen gas was measured using a VG Isotech (now GV Instruments, Wythenshawe, UK) Optima dual inlet isotope ratio mass spectrometer (IRMS).

All values are reported relative to Vienna Standard Mean Ocean Water (V-SMOW). The data are calibrated to a quartz standard (Q BLC) with a known $\delta^{18} \mathrm{O}$ value of $+8.8 \% \mathrm{~V}-\mathrm{SMOW}$ from previous measurements at the University of Paris-6 (France). This has been further calibrated for the RHUL laser line by comparison with NBS-28 quartz. Each 16-hole tray contained up to 12 sample unknowns and 4 of the Q BLC standard. For each quartz run a small constant daily correction, normally less than $0.3 \%$, was applied to the data based on the average value for the standard. Overall, the precision of the RHUL system based on standard and sample replicates is better than $\pm 0.1 \%$.

Sixteen fresh rock samples from the volcanic rocks hosting amethyst were selected for whole-rock geochemical analysis. Major elements were analyzed on lithium tetraborate glass beads by X-ray fluorescence (XRF) using a Philips PW 1410 spectrometer at the Institute of Mineralogy and Petrology at Hamburg University (Germany). Detection limits for trace elements are $10 \mathrm{ppm}$ for $\mathrm{Ba}, \mathrm{Cr}, \mathrm{Cu}$, $\mathrm{Nb}, \mathrm{Ni}, \mathrm{Pb}, \mathrm{Rb}, \mathrm{Sr}, \mathrm{V}, \mathrm{Y}, \mathrm{Zn}, \mathrm{Zr}, \mathrm{Th}, 20 \mathrm{ppm}$ for $\mathrm{La}, \mathrm{Nd}$, and $25 \mathrm{ppm}$ for Ce. The precision for major elements is better than $\pm 0.4 \%$ for $\mathrm{SiO}_{2}, \pm 0.13 \%$ for $\mathrm{Al}_{2} \mathrm{O}_{3}$ and $\mathrm{Fe}_{2} \mathrm{O}_{3}, \pm 0.22 \%$ for $\mathrm{MgO}, \pm 0.10 \%$ for $\mathrm{CaO}, \pm 0.33 \%$ for $\mathrm{Na}_{2} \mathrm{O}$, and $0.02 \%-0.04 \%$ for $\mathrm{K}_{2} \mathrm{O}, \mathrm{TiO}_{2}, \mathrm{P}_{2} \mathrm{O}_{5}$ and $\mathrm{SO}_{3}$.

\section{Geological Setting}

\subsection{Regional Geology}

The Hellenide orogen formed as a result of the collision between the African and Eurasian plates above the north-dipping Hellenic subduction zone from the Late Jurassic to the present [19]. From north to south, it consists of three continental blocks (Rhodopes, Pelagonia, and Adria-External Hellenides) and two oceanic domains (Vardar and Pindos Suture Zones) [19,20], (Figure 1a). In the Aegean region, continuous subduction of both oceanic and continental lithosphere beneath the Eurasian plate since the Early Cretaceous resulted in a series of magmatic arcs from the north (Rhodope massif) to the south (Active South Aegean Volcanic Arc) [19,21], (Figure 1a). The progressive southward migration of the magmatic centres from the Oligocene magmatic belts in the Rhodope massif, through the Miocene Aegean Islands (e.g., Limnos and Lesvos Islands) to the active South Aegean Volcanic Islands (e.g., Milos) has been attributed to slab retreat in a back-arc setting [22]. In the Rhodope Massif, Late Cretaceous-Tertiary exhumation of metamorphic core complexes along detachment faults and extensional collapse was accompanied by voluminous Late Eocene to Early Miocene calc-alkaline, high-K alkaline and shoshonitic magmatism [23-26], (Figure 1a-c). It is suggested that this magmatism in the Rhodope Massif was caused by convective removal of the lithospheric mantle (lithospheric delamination) and subsequent upwelling of the asthenosphere $[24,25,27]$. The Tertiary magmatism in the Rhodope Massif shows a decreasing influence of crustal contamination with time and an increasing input from the mantle until the eruption of purely asthenospheric magmas [25]. On Lesvos Island, thick successions of Early Miocene calc-alkaline to shoshonitic lavas and pyroclastics of basic to 
acidic composition occupy large parts of the island [27], (Figure 1d). Geochemical data suggest that the volcanic rocks on Lesvos Island (similarly to those from the Rhodope area) were derived from sub-continental lithospheric mantle and/or the lower crust, with a minimal contribution from the upper crust [27].
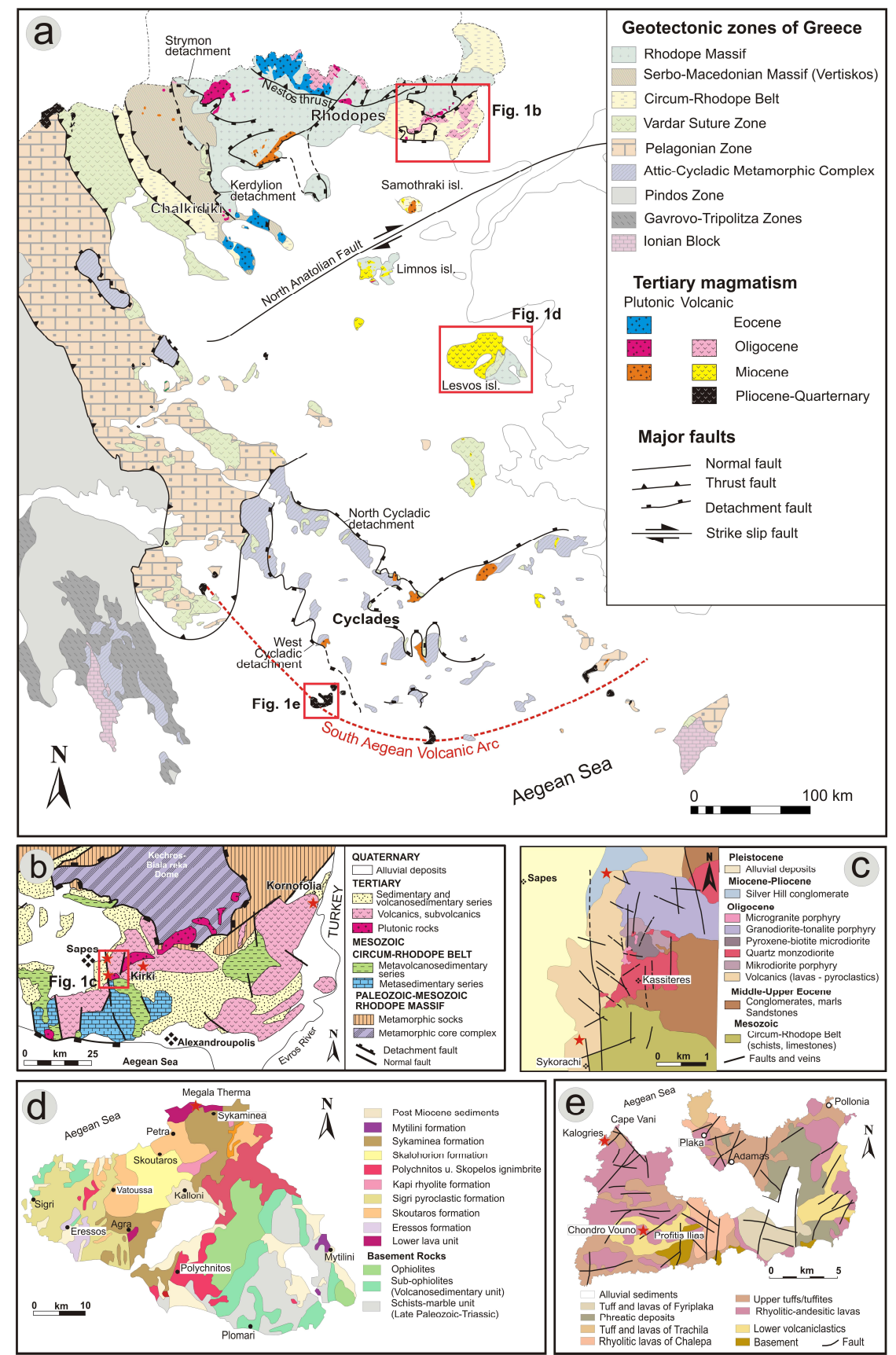

Figure 1. (a) Simplified geological map of Greece showing the main tectonic zones and the distribution of Cenozoic igneous rocks (modified after Melfos and Voudouris [26], and references therein); (b) Geological map of Western Thrace showing locations of amethyst deposits at Kornofolia, Sapes and Kirki areas (modified after Melfos and Voudouris [26]); (c) Geological map showing the location of amethyst in the Kassiteres-Sapes area (modified after Ottens and Voudouris [28]); (d) Generalized geological map of Lesvos Island and the location of amethyst at Megala Therma (modified after Innocenti et al. [23]); (e) Generalized geologic map of Milos Island depicting the location of amethyst at Kalogries and Chondro Vouno (modified after Fytikas et al. [29]). 
Finally, on Milos Island, calc-alkaline volcanic arc activity spans a period from $~ 3.5$ Ma to the present and originated from several emergent eruptive centers characterized by both explosive and effusive activity [29-31], Figure 1e). The magmatic rocks hosting amethyst mineralization are metaluminous to slightly peraluminous andesites, trachyandesites to dacites with calc-alkaline, high-K calc-alkaline to shoshonitic (e.g., Lesvos Island) character (Table 1; Figure 2). All amethyst-bearing areas host epithermal style of mineralization. They are characterized by intense hydrothermal alteration of the volcanic rocks, including adularization, sericitization, as well as propylitic, and zeolitic alteration, which are closely related to the formation of amethyst-bearing quartz veins.
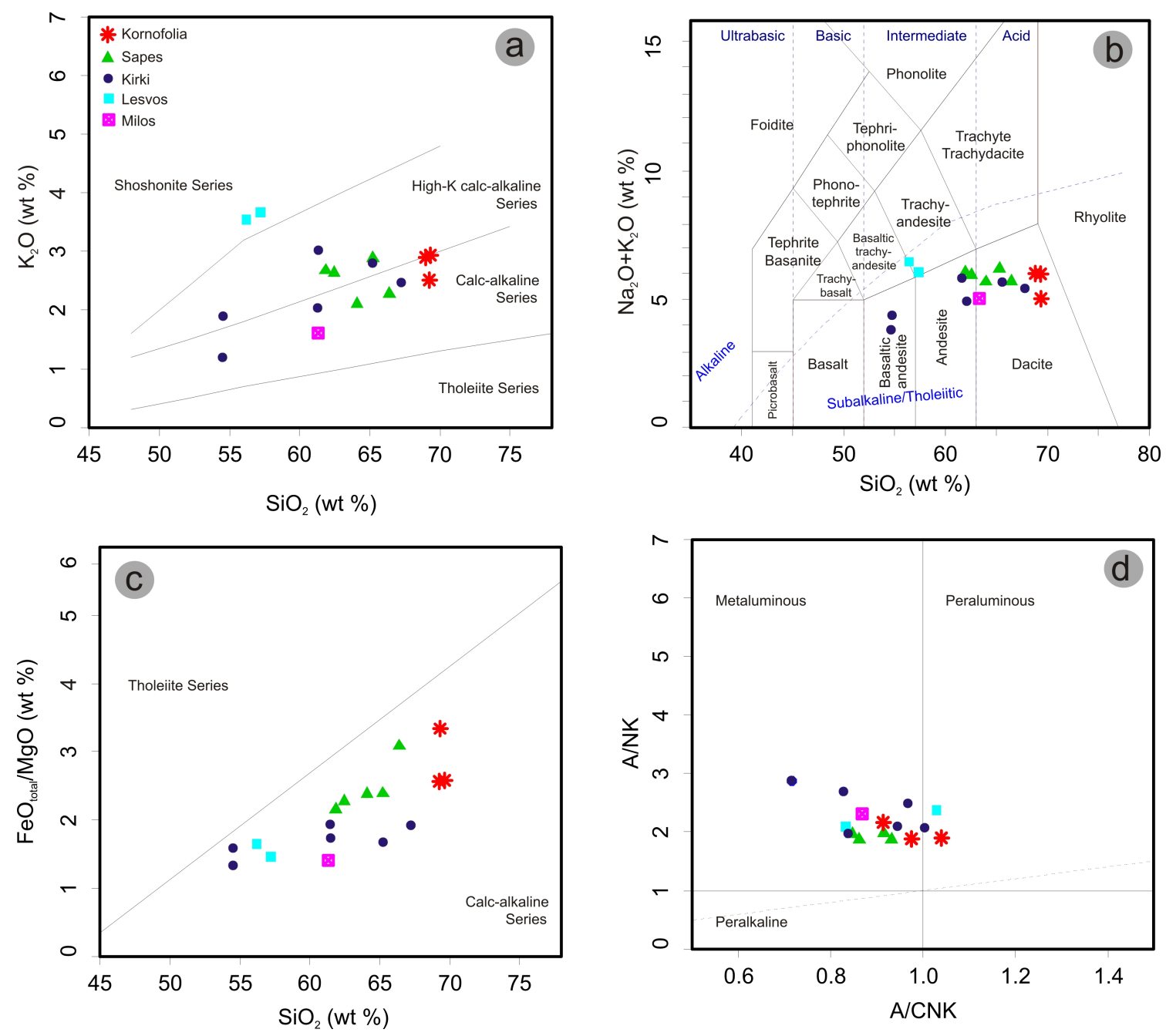

Figure 2. Classification of the studied volcanic rocks hosting amethyst mineralization in Greece. (a) $\mathrm{SiO}_{2}$ vs. $\mathrm{K}_{2} \mathrm{O}$ diagram [32]; (b) Total alkali vs. silica diagram. Rock fields are from Le Bas et al. [33], whereas the boundary between the alkaline and subalkaline fields is from Irvine and Baragar [34]; (c) $\mathrm{SiO}_{2}$ vs. $\mathrm{FeO}_{\mathrm{t}} / \mathrm{MgO}$ plot from Miyashiro [35]; (d) A/CNK vs. A/NK plot from Shand [36] discriminating metaluminous, peraluminous and peralkaline compositions. (A/NK = molar ratio of $\mathrm{Al}_{2} \mathrm{O}_{3} /\left(\mathrm{Na}_{2} \mathrm{O}+\mathrm{K}_{2} \mathrm{O}\right) ; \mathrm{A} / \mathrm{CNK}=$ molar ratio of $\left.\mathrm{Al}_{2} \mathrm{O}_{3} /\left(\mathrm{CaO}+\mathrm{Na}_{2} \mathrm{O}+\mathrm{K}_{2} \mathrm{O}\right)\right)$. 
Table 1. Chemical composition of volcanic rocks hosting amethyst at Kornofolia (1-3), Kirki (4-8), Kassiteres-Sapes (9-14), Lesvos (15-16) and Milos (17, from Liakopoulos [37]). Values for major oxides and trace elements are in wt $\%$ and ppm, respectively.

\begin{tabular}{|c|c|c|c|c|c|c|c|c|c|c|c|c|c|c|c|c|c|}
\hline & 1 & 2 & 3 & 4 & 5 & 6 & 7 & 8 & 9 & 10 & 11 & 12 & 13 & 14 & 15 & 16 & 17 \\
\hline $\mathrm{SiO}_{2}$ & 69.34 & 68.99 & 69.26 & 66.40 & 61.85 & 64.09 & 62.47 & 65.23 & 54.45 & 54.49 & 61.46 & 61.41 & 67.23 & 65.19 & 56.20 & 57.21 & 61.96 \\
\hline $\mathrm{TiO}_{2}$ & 0.46 & 0.46 & 0.50 & 0.56 & 0.59 & 0.56 & 0.54 & 0.78 & 0.75 & 0.73 & 0.62 & 0.48 & 0.48 & 0.51 & 0.85 & 1.01 & 0.66 \\
\hline $\mathrm{Al}_{2} \mathrm{O}_{3}$ & 15.54 & 15.50 & 15.02 & 16.94 & 16.36 & 16.42 & 16.18 & 16.19 & 16.78 & 15.98 & 17.31 & 16.01 & 16.01 & 16.25 & 18.12 & 18.93 & 16.57 \\
\hline $\mathrm{Fe}_{2} \mathrm{O}_{3}$ & 3.23 & 3.57 & 3.43 & 6.14 & 5.80 & 5.90 & 4.91 & 9.42 & 8.90 & 6.23 & 5.84 & 3.48 & 3.48 & 4.11 & 6.60 & 6.26 & 6.03 \\
\hline $\mathrm{MnO}$ & 0.05 & 0.06 & 0.06 & 0.12 & 0.08 & 0.08 & 0.07 & 0.09 & 0.23 & 0.13 & 0.10 & 0.08 & 0.08 & 0.11 & 0.12 & 0.11 & 0.10 \\
\hline $\mathrm{MgO}$ & 0.87 & 1.25 & 1.19 & 2.56 & 2.19 & 2.33 & 1.85 & 5.42 & 6.01 & 3.21 & 2.68 & 1.63 & 1.63 & 2.20 & 3.61 & 3.87 & 2.65 \\
\hline $\mathrm{CaO}$ & 4.18 & 3.52 & 5.22 & 5.48 & 5.29 & 6.07 & 4.80 & 9.37 & 7.73 & 6.04 & 6.01 & 4.64 & 4.64 & 5.20 & 7.20 & 5.74 & 6.63 \\
\hline $\mathrm{Na}_{2} \mathrm{O}$ & 3.12 & 3.12 & 2.56 & 3.43 & 3.63 & 3.34 & 3.35 & 2.63 & 2.51 & 2.91 & 2.92 & 2.91 & 2.91 & 2.85 & 2.94 & 2.42 & 3.33 \\
\hline $\mathrm{K}_{2} \mathrm{O}$ & 2.94 & 2.89 & 2.51 & 2.68 & 2.11 & 2.64 & 2.89 & 1.18 & 1.93 & 3.00 & 2.02 & 2.51 & 2.51 & 2.82 & 3.55 & 3.67 & 1.61 \\
\hline $\mathrm{P}_{2} \mathrm{O}_{5}$ & 0.13 & 0.14 & 0.15 & 0.11 & 0.10 & 0.10 & 0.11 & 0.14 & 0.22 & 0.14 & 0.13 & 0.13 & 0.13 & 0.12 & 0.42 & 0.48 & - \\
\hline Total & 99.86 & 99.50 & 99.99 & 99.87 & 99.24 & 99.91 & 99.93 & 99.67 & 99.54 & 99.83 & 99.04 & 99.90 & 99.10 & 99.36 & 99.61 & 99.79 & 99.87 \\
\hline $\mathrm{Ba}$ & 726 & 732 & 462 & 560 & 663 & 526 & 627 & 679 & 376 & 881 & 809 & 507 & 1175 & 705 & 1466 & 1077 & 383 \\
\hline $\mathrm{Ce}$ & 61 & 65 & 43 & 74 & 52 & 58 & 62 & 43 & - & 32 & 38 & 87 & 55 & 64 & 139 & 120 & - \\
\hline $\mathrm{Cr}$ & 6 & 5 & 8 & 14 & 12 & 12 & 12 & 10 & 89 & 135 & 40 & 20 & 10 & 19 & 16 & 34 & - \\
\hline $\mathrm{Ga}$ & 14 & 17 & 17 & 16 & 18 & 14 & 18 & 14 & 19 & 14 & 15 & 10 & - & 14 & 22 & 21 & - \\
\hline $\mathrm{La}$ & 28 & 39 & 26 & 58 & 23 & 35 & 39 & 27 & - & 16 & 29 & 38 & 13 & 46 & 88 & 57 & - \\
\hline $\mathrm{Nb}$ & 6 & 5 & 2 & 7 & 5 & 6 & 6 & 7 & 4 & 5 & 8 & 6 & 8 & 8 & - & 2 & - \\
\hline $\mathrm{Nd}$ & 28 & 27 & 20 & 25 & 24 & 23 & 24 & 17 & 9 & 14 & 15 & 4 & 16 & 25 & 55 & 50 & - \\
\hline $\mathrm{Pb}$ & 23 & 30 & 52 & 25 & 20 & 19 & 22 & 21 & - & 27 & 24 & 20 & 30 & 17 & 28 & 24 & 14 \\
\hline $\mathrm{Rb}$ & 86 & 75 & 50 & 61 & 55 & 49 & 56 & 76 & 34 & 35 & 202 & 75 & 128 & 88 & 131 & 132 & 34 \\
\hline $\mathrm{Sc}$ & 11 & 10 & 14 & 22 & 11 & 24 & 21 & 16 & - & - & - & - & - & - & 16 & 24 & - \\
\hline $\mathrm{Sr}$ & 273 & 281 & 345 & 264 & 321 & 318 & 296 & 281 & 393 & 309 & 320 & 297 & 353 & 341 & 942 & 748 & 215 \\
\hline Th & 8 & 12 & 3 & 8 & 8 & 10 & 4 & 9 & 5 & 7 & 11 & 13 & 18 & 13 & 15 & 19 & - \\
\hline $\mathrm{U}$ & 5 & 9 & 12 & 2 & 1 & 5 & 5 & 5 & - & - & - & 0 & - & - & 1 & 8 & - \\
\hline $\mathrm{V}$ & 87 & 95 & 96 & 153 & 141 & 152 & 138 & 133 & 237 & 221 & 160 & 121 & 91 & 111 & 160 & 179 & 118 \\
\hline $\mathrm{Y}$ & 22 & 25 & 22 & 25 & 32 & 26 & 22 & 24 & 27 & 25 & 27 & 28 & 20 & 22 & 24 & 25 & - \\
\hline $\mathrm{Zr}$ & 122 & 113 & 112 & 144 & 145 & 144 & 137 & 135 & 89 & 84 & 147 & 115 & 113 & 128 & 208 & 202 & - \\
\hline
\end{tabular}




\subsection{Local Geology}

\subsubsection{Northeastern Greece (Sapes, Kirki and Kornofolia)}

In northeastern Greece, amethyst mainly occurs in three epithermally altered volcanic environments of Oligocene age, namely at Kornofolia, Kassiteres-Sapes and Kirki areas [11,12,38,39], (Figure 1b,c). At Kassiteres, deep-violet amethyst occurs within colloform and crustiform banded epithermal quartz-chalcedony veins (up to $1 \mathrm{~m}$ thick), crosscutting mostly sericitic and K-feldspar (adularia) altered andesitic/dacitic lavas and pyroclastics (Figures $1 \mathrm{c}$ and $3 \mathrm{a}, \mathrm{b}$ ). The amethyst in the veins is often accompanied by gangue adularia (Figure 4a).
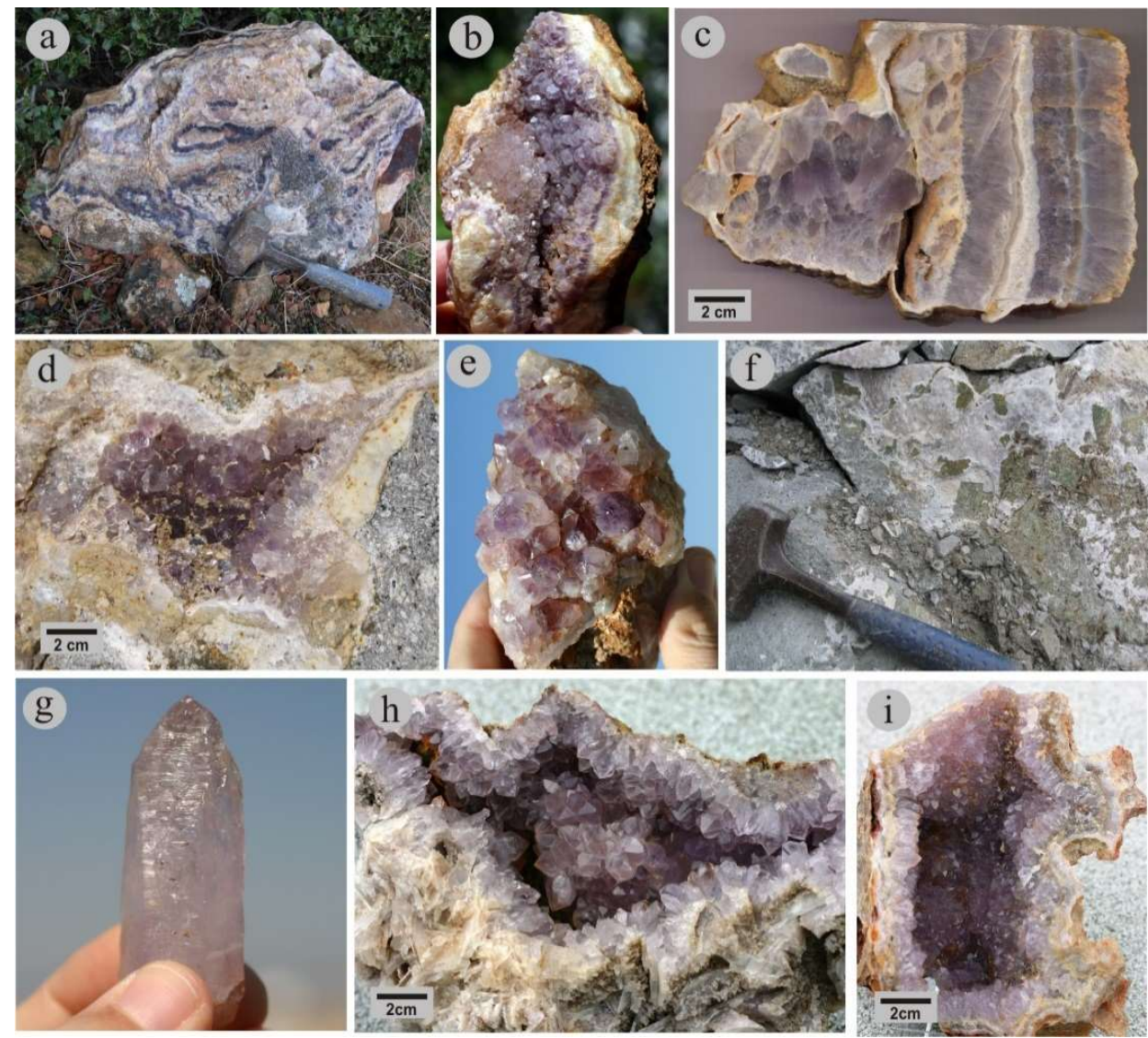

Figure 3. Field photographs and hand specimens of volcanic-hosted amethyst in Greece. (a) Boulder of dark violet amethyst alternating with chalcedony from Kassiteres, Sapes area; (b) Amethyst crystals from Kassiteres area; (c) Alternations of amethyst with chalcedony from Silver Hill, Sapes area; (d) Amethyst crystals overgrown on chalcedony within a cavity of dacite, Kornofolia area; (e) Amethyst crystals from Kornofolia area; (f) Veinlets of amethyst and calcite crosscutting zeolite-altered lavas in Kirki area; (g) Prismatic amethyst from Megala Therma, Lesvos Island; (h) Amethyst crystals associated with barite from Chondro Vouno, Milos Island; (i) Short prismatic amethyst crystals from Kalogries, Milos Island.

In the northern part of the area, massive amethyst-chalcedony boulders (up to $2 \mathrm{~m} \times 2 \mathrm{~m}$ ) occur within the "Silver Hill" conglomerate formation, which is probably a phreatomagmatic maar-diatreme breccia [40], (Figures 1c and 3c). In both localities, amethyst may also form hexagonal prismatic crystals (up to $3 \mathrm{~cm}$ in length), sometimes developing atop a lower part composed of smoky quartz. Prismatic amethyst crystals are rare. The presence of silicified wood within the tuffs hosting amethyst veins at Kassiteres-Sapes area, and the observation that the amethyst veins crosscut the fossilized wood [41], indicate probably a very shallow environment for amethyst deposition. 
In Kornofolia area, amethyst-bearing veins are hosted within zeolite-altered to fresh dacitic lavas (Figures $1 \mathrm{~b}$ and $3 \mathrm{~d}$ ). The quartz veins are composed of an external chalcedony layer, followed by deposition of coarse-grained quartz towards the vein centre. Open spaces are filled by short prismatic amethyst crystals up to $3 \mathrm{~cm}$ in length. In some veins amethyst is missing and vugs are filled by botryoidal or stalactitic pinkish chalcedony. Smectite, zeolites and calcite are accessory minerals both within the veins and in the wall rocks (Figure 4b). Similar to Kassiteres-Sapes area, in the broad Kornofolia area, the amethyst-chalcedony veins crosscut fossiliferous limestone reefs and silicified wood hosted in volcano-sedimentary layers, thus suggesting a very shallow submarine to transitional environment [41], and accordingly a very shallow depth of amethyst formation, probably close to the seafloor.
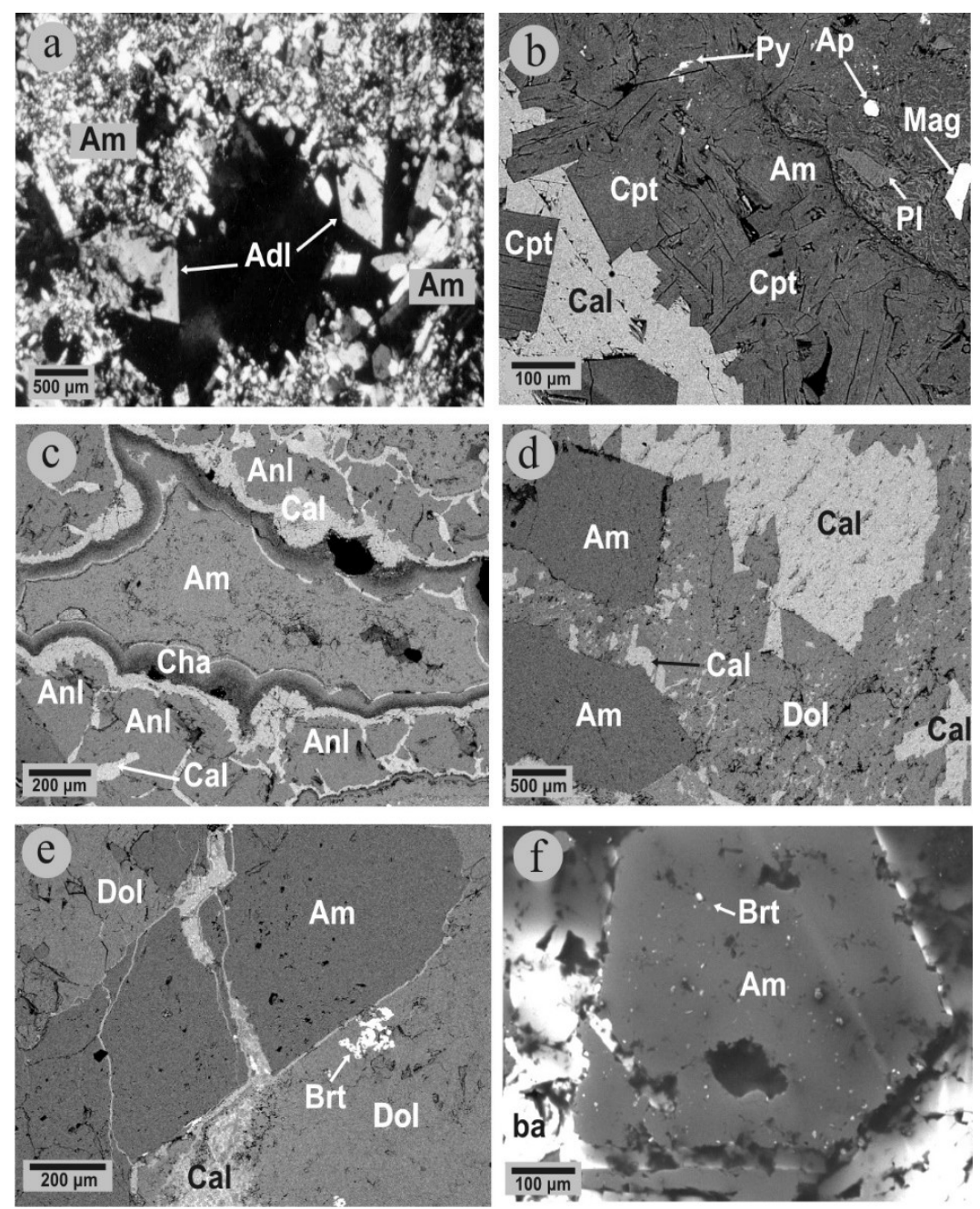

Figure 4. Microphotographs showing mineralogical assemblages of amethyst-bearing veins (a) Adularia (Adl) in association with amethyst (Am) from Kassiteres area (transmitted light, plane polarized); (b) Clinoptilolite-Ca (Cpt), including pyrite (Py), and calcite (Cal) that overgrow amethystine quartz (Am) fill cavities of dacitic lavas characterized by plagioclase (Pl) and disseminated crystals of apatite (Ap) and magnetite (Mag), Kornofolia area (SEM-BSE image); (c) Cavity filled with analcime (Anl), then calcite (Cal), which is rimmed by chalcedony (Cha), with final deposition of amethyst (Am), Kirki area (SEM-BSE image); (d,e) Amethyst (Am) is rimmed or crosscut by calcite (Cal), dolomite (Dol) and barite (Brt), Lesvos Island (SEM-BSE images); (f) Barite (Brt) included in amethyst (Am) from Milos Island (SEM-BSE image). 
Unaltered to zeolite-altered lavas of dacitic composition are the host rocks of chalcedony-amethyst bearing NNW-trending veins at Kirki area, in a locality resembling that of Kornofolia (Figures $1 \mathrm{~b}$ and 3f). Open spaces within the veins are filled by up to $1 \mathrm{~cm}$ long amethyst crystals and/or clear quartz. Amethyst in the veins is associated with the zeolites laumontite, heulandite, and analcime, and with platy calcite (Figure 4c).

\subsubsection{Lesvos Island}

In the northern part of Lesvos Island, the Megala Therma locality consists of NNE- and NW-trending amethyst-bearing epithermal veins crosscutting propylitic or sericitic altered andesitic lavas of the Lower lava unit (Figure 1d). The veins are banded and brecciated. They are composed of amethystine quartz, carbonates, chlorite and fluorite. Idiomorphic amethyst crystals up to $10 \mathrm{~cm}$ in length mostly occur in the centers of the veins. The amethyst crystals resemble those from Mexico with typical Muzo-type habit $[11,13,15]$. Sceptre and window forms are very common (Figure 3g). The Megala Therma amethyst was formed in the flanks of the Stypsi stratovolcano and probably under shallow depth. This conclusion may be derived from the fact that similar amethyst veins crosscut the central parts of the Stypsi caldera (some $\mathrm{km}$ to the south of Megala Therma), and about $150 \mathrm{~m}$ beneath a subhorizontal shallow-level advanced argillic lithocap, corresponding to the paleowater table approximately at the time of amethyst formation [42].

\subsubsection{Milos Island}

The Island of Milos represents a Plio-Pleistocene volcanic edifice with shallow submarine to subaerial, dacitic to rhyolitic subvolcanics, lavas and pyroclastics hosting epithermal-style preciousand base metal mineralization related to quartz-chalcedony veins [31]. Amethyst is present in two localities, namely the Chondo Vouno and the Kalogries area (Figure 1e). In both areas, amethyst is found within banded quartz-chalcedony-barite veins crosscutting sericitic and adularia altered rhyolitic subvolcanic bodies (Chondro Vouno) and propylitic lavas of dacitic composition (Kalogries). The veins display typical epithermal features (colloform-crustiform banding) and reach a thickness of up to $2 \mathrm{~m}$ and a length of several tens of meters [31,43]. Chalcedonic quartz is deposited on both sides of the vein walls and is followed by the formation of amethyst crystals (reaching up to $3 \mathrm{~cm}$ in length at Chondro Vouno) in the center of the veins (Figure 3h,i). Amethyst in Kalogries area (Figure 3i) is overgrown by late botryoidal aragonite. A very shallow submarine to subaerial environment of amethyst formation at Kalogries is evidenced by the presence of fossilized vertabrates within volcanoclastic material overlying the lavas, which are crosscut by the quartz-chalcedony veins [44]. We suggest that amethyst at Kalogries formed at, or just below the seafloor level, at a water depth not exceeding $100 \mathrm{~m}$.

\section{Mineralogy and Mineral Chemistry}

Amethyst in the veins is accompanied by various mineralogical associations, suggesting specific conditions of crystallization. Quartz (var. amethyst) and chalcedony are by far the most abundant minerals in the veins, while other vein minerals include carbonates, barite, zeolites, chlorite, adularia and in minor amounts pyrite, smectite, goethite and lepidocrocite (Figure 4). Microanalyses are presented in Table 2 and the mineral-chemical data are plotted in terms of binary and ternary diagrams (Figure 5).

Adularia is present as vein and wallrock alteration mineral in Kassiteres and Silver Hill at Sapes, as well as at the Chondro Vouno amethyst deposits. In the K-feldspar alteration zones, adularia usually replaces plagioclase, primary clinopyroxene and amphibole of the volcanic host rocks. In the veins, adularia forms idiomorphic crystals (Figure 4a), overgrows amethyst crystals or can be present as inclusions in amethystine quartz. Microanalyses revealed a stoichiometric composition for the adularia from Sapes area, with Ba up to $0.7 \mathrm{wt} \%$, substituting for $\mathrm{K}$. A small percentage of $\mathrm{Na}_{2} \mathrm{O}$ (up to $0.32 \mathrm{wt} \%$ ) also substitutes for K (Table 2). 

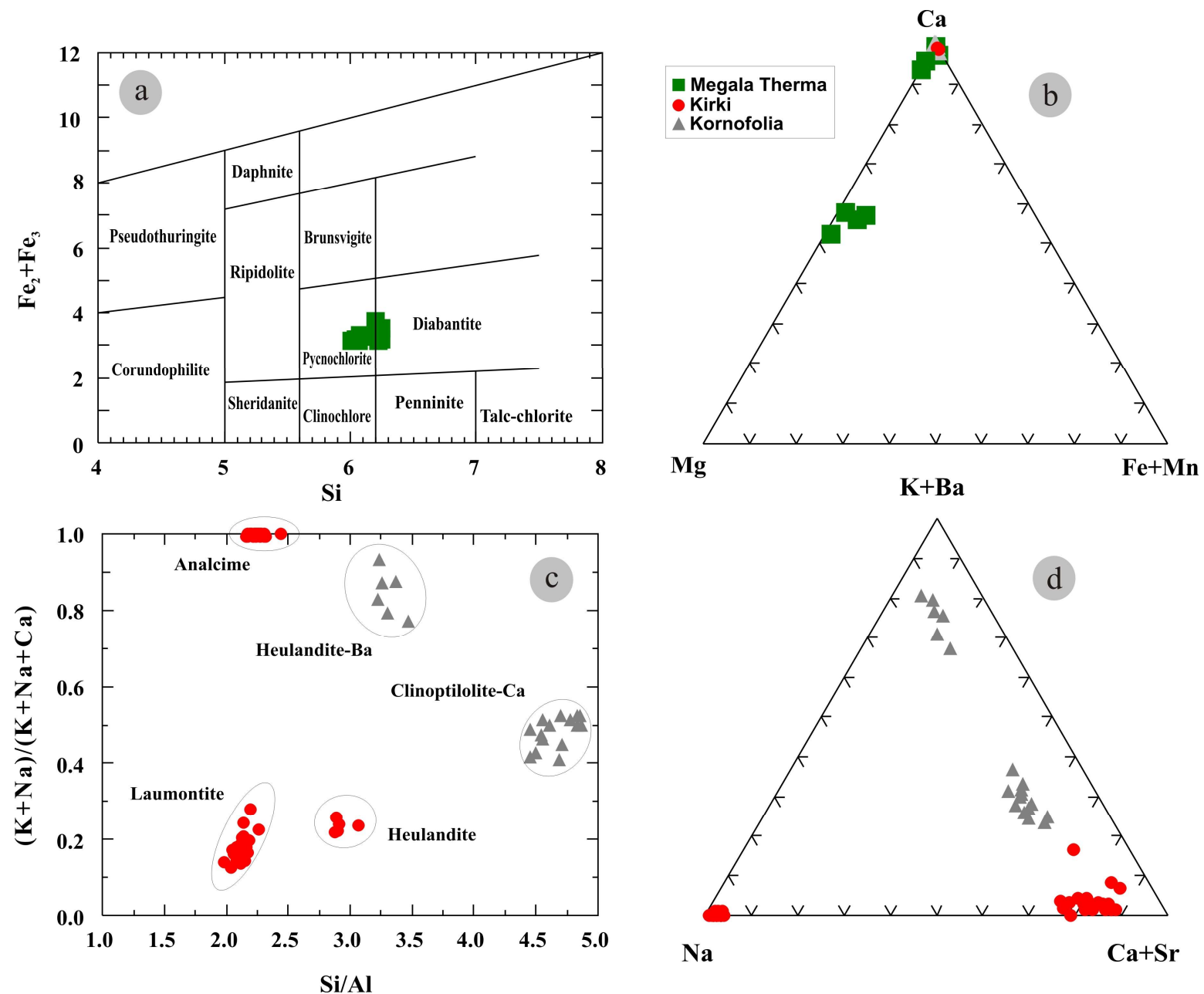

Figure 5. (a) Binary $\mathrm{Fe}_{\text {total }}$-Si classification diagram of chlorite from Lesvos amethyst deposit (after Hey [45]); (b) Ternary Ca-Mg-Mn plot for calcite and dolomite associated with amethyst from Kirki, Kornofolia and Lesvos Island; (c) Binary plot $((\mathrm{K}+\mathrm{Na}) /(\mathrm{Ca}+\mathrm{Na}+\mathrm{K}))$ versus $(\mathrm{Si} / \mathrm{Al})$ of zeolites accompanying amethyst; (d) Ternary Ba-K-Na plot of zeolites related with amethyst.

Chlorite occurs in minor amounts in the amethyst-bearing veins at Megala Therma in association with carbonates and barite. It is a common mineral in the propylitic altered lavas hosting the amethyst, where, in conjunction with carbonates and sericite, it replaces pyroxene and hornblende phenocrysts. Microanalyses of vein chlorite are presented in Table 2. The Lesvos chlorites are classified as pycnochlorite and diabantite (Figure 5a).

Calcite and dolomite accompany amethyst at Megala Therma, Lesvos Island, Kornofolia and Kirki (Figure $4 b-e$ ). In the last two localities, calcite pre- and / or postdates amethyst in the veins (Figure $4 b, c)$. At Megala Therma, the amethyst crystals are overgrown and crosscut first by dolomite and then by calcite and barite (Figure $4 \mathrm{~d}, \mathrm{e}$ ). Microanalyses indicated up to $18.1 \mathrm{wt} \% \mathrm{MgO}$ and $1.93 \mathrm{wt} \% \mathrm{FeO}$ substituting for $\mathrm{Ca}$ in the dolomite (Table 2). Minor amounts of $\mathrm{Mn}$ ( $\mathrm{MnO}$ up to $0.8 \mathrm{wt} \%$ ) and $\mathrm{Sr}(\mathrm{SrO}$ up to $0.2 \mathrm{wt} \%$ ), are detected in calcite from Kornofolia and Lesvos, respectively (Table 2, Figure $5 b$ ).

Barite accompanies amethyst in the veins of Kalogries and Chondro Vouno, where it pre- or postdates amethyst deposition. At Kalogries, it can also be found as inclusions in amethyst and chalcedony (Figure 3f). The Milos barite contains up to $3.41 \mathrm{wt} \% \mathrm{SrO}$, substituting for $\mathrm{Ba}$ in the structure. It also occurs in minor amounts at Megala Therma and in the Kassiteres and Silver Hill amethyst occurrences. 
Table 2. Representative chemical microanalyses of silicates and carbonates associated with amethyst: 1-3: adularia (Kassiteres); 4, 5: chlorite (Megala Therma, Lesvos); 6, 7: calcite, dolomite (Lesvos); 8: calcite (Kornofolia); 9: calcite (Kirki); 10, 11: clinoptilolite-Ca (Kornofolia); 12, 13: heulandite-Ba (Kornofolia); 14, 15: analcime (Kirki); 16: laumontite (Kirki); bd = below detection limit, na = not analyzed, $\mathrm{Ctn}=$ cations.

\begin{tabular}{|c|c|c|c|c|c|c|c|c|c|c|c|c|c|c|c|c|}
\hline & 1 & 2 & 3 & 4 & 5 & 6 & 7 & 8 & 9 & 10 & 11 & 12 & 13 & 14 & 15 & 16 \\
\hline $\mathrm{SiO}_{2}$ & 66.15 & 65.63 & 65.77 & 30.41 & 31.50 & na & na & na & na & 66.36 & 67.56 & 53.27 & 53.48 & 56.38 & 55.12 & 51.36 \\
\hline $\mathrm{Al}_{2} \mathrm{O}_{3}$ & 17.92 & 18.19 & 18.30 & 17.60 & 19.65 & na & na & na & na & 11.69 & 12.31 & 13.37 & 13.97 & 20.85 & 20.51 & 21.28 \\
\hline $\mathrm{FeO}$ & 0.03 & $\mathrm{bd}$ & 0.01 & 20.48 & 19.81 & 0.08 & 1.93 & 0.12 & 0.36 & 0.11 & 0.10 & 1.01 & 0.39 & bd & 0.02 & $\mathrm{bd}$ \\
\hline $\mathrm{MgO}$ & na & na & na & 17.15 & 17.83 & 0.16 & 18.06 & $\mathrm{bd}$ & 0.08 & $\mathrm{bd}$ & 0.08 & 0.29 & 0.02 & 0.08 & $\mathrm{bd}$ & $\mathrm{bd}$ \\
\hline $\mathrm{MnO}$ & na & na & na & 0.37 & 0.39 & $\mathrm{bd}$ & bd & 0.82 & 0.45 & $\mathrm{bd}$ & 0.09 & 0.05 & bd & 0.04 & $\mathrm{bd}$ & $\mathrm{bd}$ \\
\hline $\mathrm{CaO}$ & $\mathrm{bd}$ & 0.01 & $\mathrm{bd}$ & 0.71 & 0.45 & 50.03 & 29.53 & 49.00 & 49.24 & 3.95 & 4.38 & 0.55 & 0.50 & 0.04 & 0.11 & 10.37 \\
\hline $\mathrm{Na}_{2} \mathrm{O}$ & 0.04 & 0.08 & 0.26 & 0.63 & 0.65 & na & na & na & na & 0.90 & 0.68 & 0.66 & 0.90 & 10.97 & 11.52 & 0.59 \\
\hline $\mathrm{K}_{2} \mathrm{O}$ & 16.13 & 16.54 & 15.99 & 0.04 & 0.19 & na & na & na & na & 1.97 & 1.64 & 1.88 & 4.18 & 0.05 & $\mathrm{bd}$ & 0.89 \\
\hline $\mathrm{SrO}$ & na & na & na & 0.86 & 0.11 & bd & 0.18 & 0.01 & $\mathrm{bd}$ & 2.33 & 1.59 & 0.79 & 1.87 & 0.43 & 0.58 & 1.10 \\
\hline $\mathrm{BaO}$ & 0.03 & 0.20 & 0.55 & na & na & na & na & $\mathrm{bd}$ & $\mathrm{bd}$ & 0.52 & 0.29 & 15.97 & 14.66 & $\mathrm{bd}$ & $\mathrm{bd}$ & 0.14 \\
\hline Total & 100.33 & 100.65 & 100.88 & 87.64 & 90.60 & 50.27 & 49.7 & 49.95 & 50.13 & 87.84 & 88.72 & 87.87 & 90.56 & 88.80 & 87.86 & 85.73 \\
\hline Atoms & $8(\mathrm{O})$ & $8(\mathrm{O})$ & $8(\mathrm{O})$ & $28(\mathrm{O})$ & $28(\mathrm{O})$ & 1 (Ctn) & $2(\mathrm{Ctn})$ & 1 (Ctn) & 1 (Ctn) & $72(\mathrm{O})$ & $72(\mathrm{O})$ & $72(\mathrm{O})$ & $72(\mathrm{O})$ & $96(\mathrm{O})$ & $96(\mathrm{O})$ & $48(\mathrm{O})$ \\
\hline $\mathrm{Si}$ & 3.03 & 3.02 & 3.01 & 6.23 & 6.20 & - & - & - & - & 29.61 & 29.52 & 27.27 & 26.82 & 33.72 & 33.60 & 16.14 \\
\hline $\mathrm{Al}$ & 0.97 & 0.98 & 0.99 & 4.24 & 4.55 & - & - & - & - & 6.12 & 6.30 & 8.10 & 8.28 & 14.76 & 14.76 & 7.86 \\
\hline $\mathrm{Fe}^{3+}$ & 0.00 & 0.00 & 0.00 & 0.24 & 0.32 & 0.00 & 0.05 & 0.00 & 0.01 & 0.00 & 0.00 & 0.45 & 0.18 & 0.00 & 0.00 & 0.00 \\
\hline $\mathrm{Fe}^{2+}$ & 0.00 & 0.00 & 0.00 & 3.24 & 2.90 & 0.00 & 0.00 & 0.00 & 0.00 & 0.00 & 0.00 & 0.00 & 0.00 & 0.00 & 0.00 & 0.00 \\
\hline $\mathrm{Mg}$ & - & - & - & 5.22 & 5.22 & 0.01 & 0.90 & 0.00 & 0.00 & 0.00 & 0.09 & 0.18 & 0.00 & 0.00 & 0.00 & 0.00 \\
\hline $\mathrm{Mn}$ & - & - & - & 0.07 & 0.07 & 0.00 & 0.00 & 0.01 & 0.01 & 0.00 & 0.00 & 0.00 & 0.00 & 0.00 & 0.00 & 0.00 \\
\hline $\mathrm{Ca}$ & 0.00 & 0.00 & 0.00 & 0.11 & 0.11 & 0.99 & 1.05 & 0.99 & 0.98 & 1.89 & 2.07 & 0.27 & 0.27 & 0.00 & 0.12 & 3.48 \\
\hline $\mathrm{Na}$ & 0.00 & 0.01 & 0.02 & 0.25 & 0.25 & - & - & - & - & 0.81 & 0.54 & 0.63 & 0.90 & 12.72 & 13.56 & 0.36 \\
\hline K & 0.94 & 0.97 & 0.94 & 0.04 & 0.04 & - & - & - & - & 1.08 & 0.90 & 1.26 & 2.70 & 0.00 & 0.00 & 0.36 \\
\hline $\mathrm{Sr}$ & - & - & - & 0.11 & 0.00 & 0.00 & 0.00 & - & - & 0.63 & 0.36 & 0.27 & 0.54 & 0.12 & 0.24 & 0.18 \\
\hline $\mathrm{Ba}$ & 0.00 & 0.00 & 0.01 & - & - & - & - & - & - & 0.09 & 0.09 & 3.24 & 2.88 & 0.00 & 0.00 & 0.00 \\
\hline
\end{tabular}


Clinoptilolite-Ca and heulandite-Ba at Kornofolia, and analcime, laumontite and heulandite at Kirki are closely related with amethyst in the veins (Figure 4b-d). At Kornofolia, a chalcedony layer overgrows zeolitized wallrocks followed by deposition of amethyst, then by heulandite-Ba included in clinoptilolite-Ca [46,47] and finally calcite (Figure 4b). Deposition in the Kirki veins started with alternations of thin layers of quartz, smectite, laumontite and heulandite, then analcime and calcite, followed by chalcedony, and finally by amethyst, which forms short prismatic crystals in the centre of the veins (Figure 4c). Microanalyses of clinoptilolite indicated an almost stoichiometric composition, with relatively elevated contents of Ca and K corresponding up to 4.6 and $2.4 \mathrm{wt} \%$, respectively (Table 2). The analysed heulandite-Ba from Kornofolia revealed variable cation contents with $\mathrm{K}\left(\mathrm{K}_{2} \mathrm{O}\right.$ up to $\left.4.2 \mathrm{wt} \%\right)$ substituting for $\mathrm{Na}$ and relatively high $\mathrm{Ba}$ contents ( $\mathrm{BaO}$ up to $15.97 \mathrm{wt} \%$ ), corresponding to $3.24 \mathrm{apfu}$. Microanalyses of analcime from Kirki revealed stoichiometric compositions with a stable $(\mathrm{K}+\mathrm{Na}) /(\mathrm{K}+\mathrm{Na}+\mathrm{Ca})$ ratio close to 1 , whereas the $\mathrm{Si} / \mathrm{Al}$ ratio shows a small variance between 2.0 and 2.4 (Table 2, Figure $5 \mathrm{c}, \mathrm{d}$ ).

Pyrite and smectite at Kornofolia and Kirki predate amethyst in the veins, whereas goethite and lepidocrocite are included in amethyst at Chondro Vouno [48].

\section{Fluid Inclusions}

\subsection{Morphology and Types of Fluid Inclusions}

Fluid inclusions were studied in amethysts from all localities apart from Kirki where the samples did not contain any inclusions. The samples contain clear, sometimes strained, granular euhedral amethystine quartz crystals. These crystals were formed filling open spaces in colloform and crustiform banded epithermal veins of the volcanic rocks. Chalcedony often forms an external selvage along the veins. Fluid inclusions in amethyst occur mainly close to the external rather than the internal part of the crystals in the veins where they are more scattered.

Fluid inclusions were studied in the amethysts on the basis of the criteria introduced by Roedder [49], Van den Kerkhof and Hein [50], and Goldstein and Reynolds [51], such as shape similarity, size diversity, constant liquid to vapour ratios and the occurrence along growth zones. All studied fluid inclusions are two-phase aqueous liquid-vapour (Figure 6a) with almost constant liquid-vapour ratios ( 10 volume \% vapor in Silver Hill, Megala Therma, Chondro Vouno and Kalogries, and $\sim 20$ volume \% vapor in Kassiteres and Kornofolia). During microthermometry analysis, they homogenized to the liquid upon heating.

Post-entrapment phenomena, such as necking down or leakage of fluid inclusions, were observed in most localities. Liquid- or vapour-only fluid inclusions in Soufli, Lesvos and Milos arranged along healed fractures possibly show a significant post-entrapment modification due to leakage. Necking and leakage phenomena were observed in the amethysts of Kassiteres, Soufli, Lesvos and Chondro Vouno of Milos producing a significant amount of vapour (Figure $6 b, c)$. These inclusions are characterized by variable liquid to vapour ratio.

All inclusions affected by post-entrapment modifications are frequently found along healed micro-cracks of amethyst grains (Figure 6c) due to mechanical intracrystalline strain, as described by Audétat and Günther [52], Tarantola et al. [53,54], Diamond and Tarantola [55], and Stünitz et al. [56]. Volume changes of the inclusions are probably attributed to a "stretching" process which may lead to multiple micro-fractures that induce leakage of fluid inclusions after trapping and expanding of the vapour phase [57,58] (Figure 6b). These inclusions were avoided in this study. Furthermore, post-entrapment "stretching" processes destroyed the fluid inclusions in amethysts from Kirki; therefore, no workable inclusions were found in the amethysts from this site. The impact of post-entrapment modifications on amethyst inclusions was minimized by selecting only regularly-shaped inclusions with constant liquid to vapour ratios.

Most fluid inclusions are arranged in clusters or along trails. The trails underline either crystal growth zones (Figure 6d) demonstrating a primary origin of the inclusions, or occur within the grains 
along healed intragranular micro-cracks as pseudosecondary inclusions (Figure 6e) as a result of fracturing during growth of the crystals. The studied fluid inclusions have a maximum length of $75 \mu \mathrm{m}$ but mostly ranges between 6 and $20 \mu \mathrm{m}$. The largest inclusions occur in Megala Therma amethysts. Isolated inclusions with negative-crystal shape are rare.
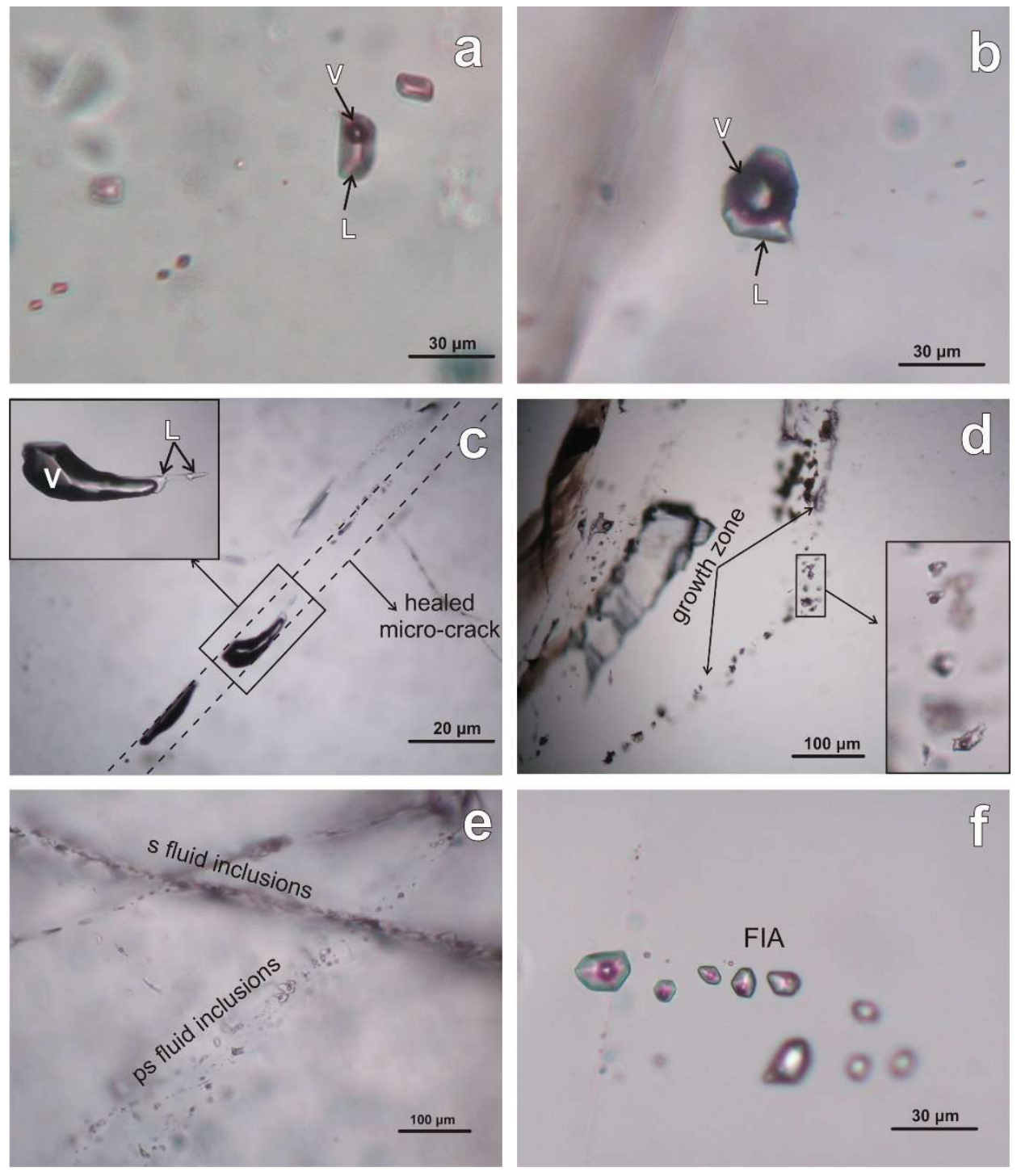

Figure 6. Photomicrographs of fluid inclusion populations from the studied amethysts under plane polarized light. (a) Primary two-phase liquid-rich fluid inclusion (Kornofolia of Sapes, sample AS1); (b) vapor-rich fluid inclusion with leakage phenomena due to "stretching" processes (Megala Therma of Lesvos, sample LS1); (c) deformed and stressed vapor-rich fluid inclusions along healed micro-cracks of amethyst (Megala Therma of Lesvos, sample LS1); (d) primary FIA suitable for microthermometry along a growth zone and a close-up photo showing two-phase fluid inclusions (Megala Therma of Lesvos, sample LS3); (e) pseudosecondary (ps) two-phase liquid-rich inclusions crosscut by later secondary (s) inclusions (Kalogries of Milos, sample ML2); (f) a FIA which includes a group of fluid inclusions formed under the same temperature and pressure (Megala Therma of Lesvos, sample LS1). L liquid phase, V vapour phase, FIA Fluid inclusion assemblage.

Fluid inclusions were evaluated based on fluid inclusion assemblages (FIAs; Figure 6f). A FIA defines a group of coeval and cogenetic fluid inclusions that trapped a fluid of the same chemical composition [51]. This implies that they were formed under the same temperature and pressure 
conditions. Amethysts contain three well defined types of FIAs with primary, pseudosecondary and secondary inclusions. The primary origin of FIAs in the studied amethysts is identified by the parallel groups of fluid inclusions along the growth zones and crystal faces (Figure 6d).

In addition to the primary FIAs, pseudosecondary fluid inclusion assemblages were also used for microthermometry as they represent fluids which were incorporated before amethyst growth was complete [59]. They were trapped in intragranular fractures caused by internal stresses in the host crystal due to rapid growth or by external rock stresses which are mechanically transferred to the host crystal. Pseudosecondary FIAs are arranged along trails which are crosscut by secondary fluid inclusions, interpreted to be older in age (Figure 6e).

Secondary inclusions are distributed along trails and planes in healed microfractures and are interpreted as late, post-dating amethyst crystallization. Besides their relation with host-crystals, pseudosecondary and secondary inclusions are difficult to distinguish. In the studied samples the secondary inclusions did not have constant volumes thus resulting in highly variable microthermometric data, especially Th. This was interpreted as probably due to the post-entrapment refilling of the fluid inclusions with a single phase in the area of intersection, as it was described by Goldstein [59]. These inclusions are interpreted as secondary and as a consequence they do not represent the original fluid trapped during amethyst formation and were not considered in the further discussion.

\subsection{Microthermometry}

Microthermometric results of the studied fluid inclusions are summarized in Table 3. The primary inclusions trapped along growth zones and the pseudosecondary trails show similar homogenization temperatures $\left(T_{h}\right)$ and salinities. Freezing of the fluid inclusions hosted within the studied amethysts revealed apparent eutectic temperatures $\left(\mathrm{T}_{\mathrm{e}}\right)$ between -22.5 and $-21.0^{\circ} \mathrm{C}$, indicating that the dissolved salt is dominated by $\mathrm{NaCl}$ with very likely the presence of $\mathrm{KCl}$ [60].

The temperatures of final ice melting $\left(\mathrm{T}_{\mathrm{m} \text { (ice) }}=-1.2\right.$ to $\left.-0.5^{\circ} \mathrm{C}\right)$ in amethyst from Silver Hill at Sapes indicate salinities of 0.9 to $2.1 \mathrm{wt} \% \mathrm{NaCl}$ equiv [17,61]. Homogenization temperatures range from 188 to $246^{\circ} \mathrm{C}$ (Figure 7a). A total of 8 primary or pseudosecondary FIAs were analyzed. Two-phase fluid inclusions within single FIAs homogenized within ranges of 2 to $19^{\circ} \mathrm{C}$. This consistency confirms that the inclusions are part of a FIA which trapped a single homogeneous fluid not affected by subsequent geological events [51]. These temperatures consistently decrease with decreasing age of the inclusions and host minerals. Older amethysts close to the vein walls contain FIAs that homogenized between 201 and $230^{\circ} \mathrm{C}$ while younger amethysts contain inclusions that homogenized from 189 to $205{ }^{\circ} \mathrm{C}$ (Table 3). Fluid inclusions with higher or lower homogenization temperatures $\left(\mathrm{T}_{\mathrm{h}}>230{ }^{\circ} \mathrm{C}\right.$ or $<189^{\circ} \mathrm{C}$ ) than the majority of the data are attributed to post-entrapment phenomena rather than heterogeneous entrapment $[55,62,63]$. Similar salinity and $\mathrm{T}_{\mathrm{h}}$ in fluid inclusions in amethysts from Silver Hill were reported by Melfos [12].

Fluid inclusions in amethysts from Kassiteres exhibit low salinities $(0.5-3.4 \mathrm{wt} \% \mathrm{NaCl}$ equiv)

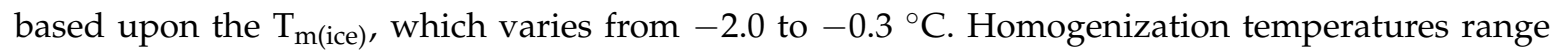
between 211 and $275{ }^{\circ} \mathrm{C}$ (Figure $7 \mathrm{~b}$ ) and show a progressive $\mathrm{T}_{\mathrm{h}}$ decrease from hotter fluids $\left(T_{h}=238-275{ }^{\circ} \mathrm{C}\right)$ in the amethyst crystals close to the vein walls to cooler fluids $\left(T_{h}=211-239{ }^{\circ} \mathrm{C}\right)$ at the inner parts of the veins (Table 3).

The FIAs of amethysts from Kornofolia of Soufli exhibit $\mathrm{T}_{\mathrm{m} \text { (ice) }}$ of -2.8 to $-1.2{ }^{\circ} \mathrm{C}$, which corresponds to a fluid salinity between 2.1 and $4.7 \mathrm{wt} \% \mathrm{NaCl}$ equiv. The inclusions homogenized at a large variety of temperatures from 168 to $297^{\circ} \mathrm{C}$ (Figure 7c). Based on five primary two-phase fluid inclusion assemblages, the homogenization temperatures are clustered between 191 and $223^{\circ} \mathrm{C}$, showing that the assemblages are true FIAs and, therefore, this range probably correspond to a homogeneous fluid. Fluid inclusions which homogenized at higher or lower temperatures $\left(>223^{\circ} \mathrm{C}\right.$ or $<191{ }^{\circ} \mathrm{C}$ ) are considered to have stretched or leaked after entrapment. Melfos [12] reported 
similar salinity but higher homogenization temperatures, up to $378^{\circ} \mathrm{C}$, which may be attributed to post-entrapment processes.

In Megala Therma of Lesvos Island the salinity of the fluid inclusions in amethyst varies from 3.1 to $4.8 \mathrm{wt} \% \mathrm{NaCl}$ equiv $\left(\mathrm{T}_{\mathrm{m} \text { (ice) }}=-2.9\right.$ to $-1.8^{\circ} \mathrm{C}$ ). Homogenization temperatures range between 211 and $250{ }^{\circ} \mathrm{C}$, with a maximum at $230^{\circ} \mathrm{C}$ (Figure $7 \mathrm{~d}$ ). Primary two-phase fluid inclusions in most FIAs show two $\mathrm{T}_{\mathrm{h}}$ clusters: $235-246^{\circ} \mathrm{C}$ (4 FIAs) and $219-235^{\circ} \mathrm{C}$ (5 FIAs) (Table 3). These amethysts appear to have trapped more than one episode of fluid flow and possibly correspond to different crystal formation stages. The earlier stage with higher $T_{h}$ corresponds to the basal parts of the amethyst, closer to the vein selvage, whereas the later stage with slightly lower $T_{h}$ characterizes the outer parts of the crystals towards the vein centre. A few inclusions with high temperatures of homogenization $\left(>246^{\circ} \mathrm{C}\right)$ reported in this study are interpreted as due to post-entrapment changes.

Table 3. Homogenization temperatures and salinity of fluid inclusions in volcanogenic amethysts from Greece. Salinities were calculated based on equations of Bodnar [17] in the system $\mathrm{H}_{2} \mathrm{O}-\mathrm{NaCl}$. ( $\mathrm{FI}=$ fluid inclusion; FIA = fluid inclusions assemblage; $\mathrm{L}=$ liquid phase, $\mathrm{V}=$ vapour phase; equiv = equivalent; $n=$ number of microthermometric analyses in each FIA; n.a. = not analysed).

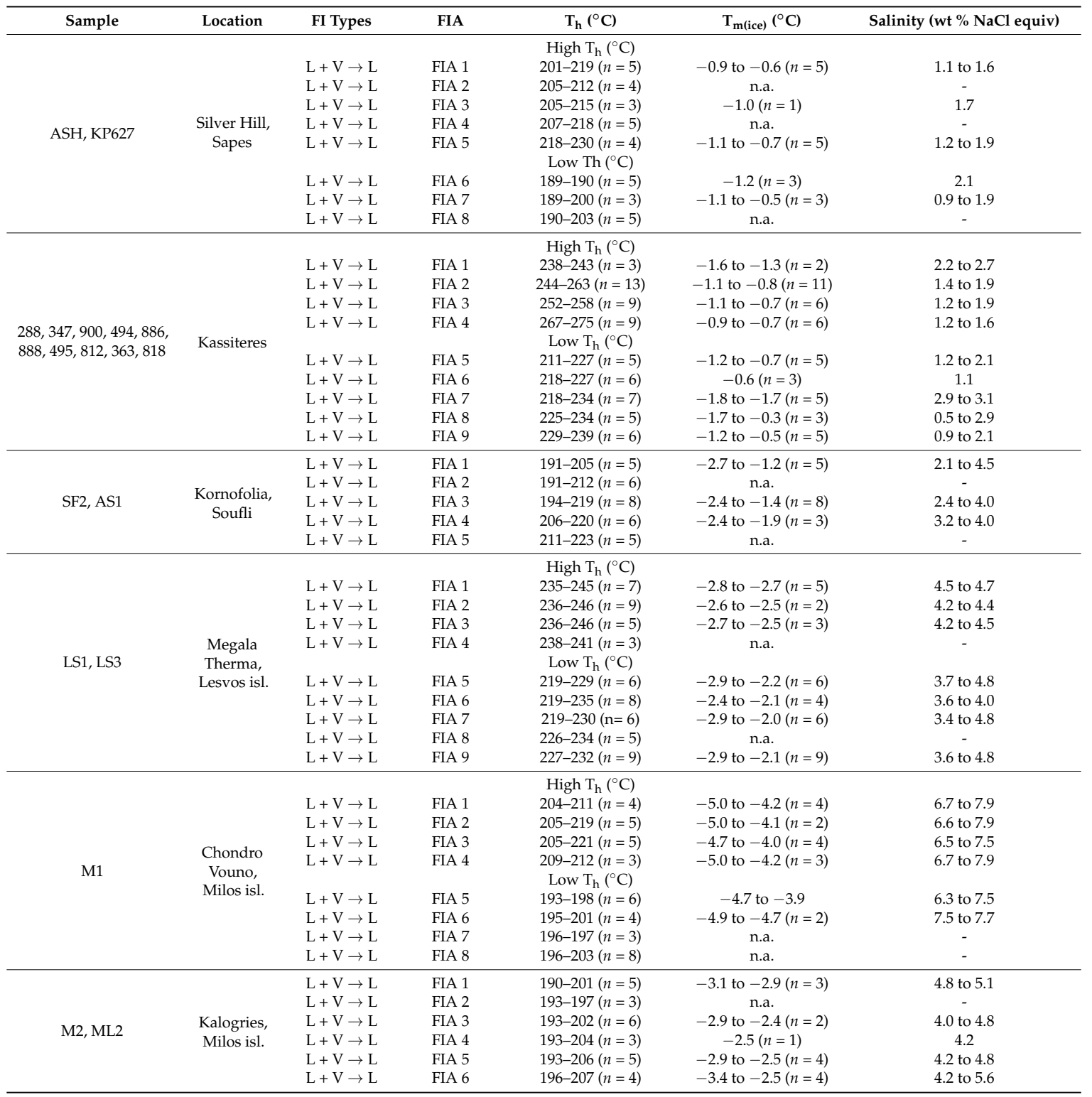



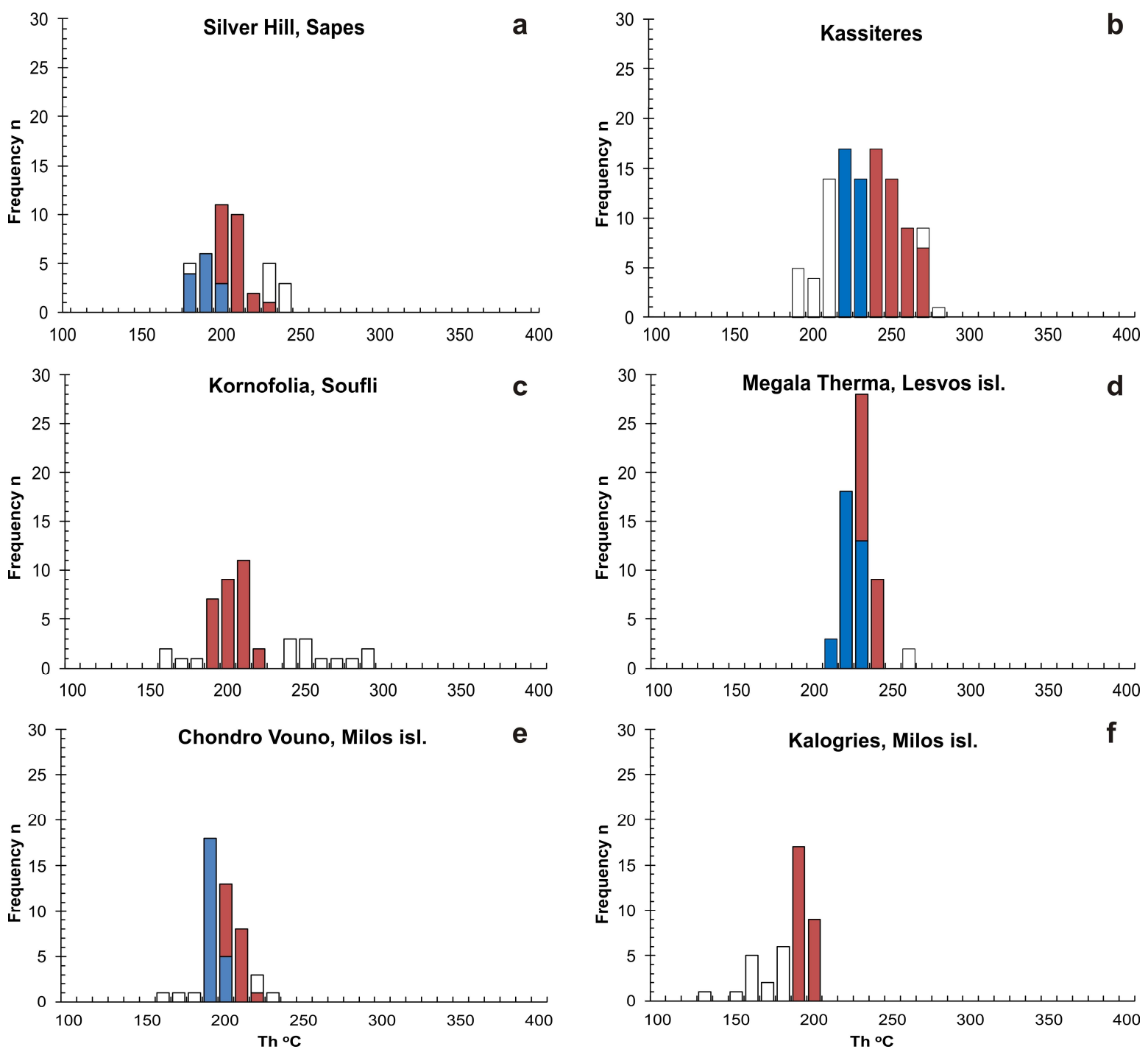

Figure 7. Distribution of the homogenization temperatures of fluid inclusions from various amethyst occurrences in volcanic rocks from Greece (a) Silver Hill from Sapes; (b) Kassiteres; (c) Kornofolia from Soufli; (d) Megala Therma from Lesvos island; (e) Chondro Vouno and (f) Kalogries from Milos island. Red bars represent older FIAs with higher $T_{h}$ at the external parts of the amethysts and blue bars correspond to younger FIAs with the lower $\mathrm{T}_{\mathrm{h}}$ at the inner crystal parts. White bars show $\mathrm{T}_{\mathrm{h}}$ of fluid inclusions affected by post-entrapment processes and were not considered for any further interpretation.

The final ice melting temperatures of fluid inclusions $\left(\mathrm{T}_{\mathrm{m} \text { (ice) }}=-5.1\right.$ to $\left.-3.2{ }^{\circ} \mathrm{C}\right)$ in amethysts from Chondro Vouno on Milos Island reveal low to moderate salinities of 5.3 to $8.0 \mathrm{wt} \% \mathrm{NaCl}$ equiv. The inclusions homogenized at temperatures between 164 and $232{ }^{\circ} \mathrm{C}$ (Figure 7e). A total of 8 FIAs of two-phase inclusions were selected for microthermometric analyses (Table 3). The higher temperature hydrothermal fluids from which the amethyst crystals grew is represented by two FIAs that contain inclusions with Th of 204 to $221^{\circ} \mathrm{C}$. A second and slightly cooler fluid is reported by four FIAs within a homogenization temperature range of 193 to $203^{\circ} \mathrm{C}$.

Low salinities ( 3.4 to $5.6 \mathrm{wt} \% \mathrm{NaCl}$ equiv) obtained from the final ice melting temperatures $\left(\mathrm{T}_{\mathrm{m} \text { (ice) }}=-3.4\right.$ to $-2.0^{\circ} \mathrm{C}$ ) were recorded in the fluid inclusions from the amethysts of Kalogries on Milos Island. The inclusions homogenized at temperatures between 139 and $209^{\circ} \mathrm{C}$, but the majority of homogenization temperatures are scattered from 190 to $200{ }^{\circ} \mathrm{C}$ (Figure $7 \mathrm{f}$ ). This is also confirmed by 
the $\mathrm{T}_{\mathrm{h}}$ observed in six FIAs which ranges from 190 to $207^{\circ} \mathrm{C}$. Lower homogenization temperatures $\left(<193^{\circ} \mathrm{C}\right)$ of the fluid inclusions are attributed to post-entrapment phenomena and were rejected from the dataset.

\section{Amethyst Oxygen Isotopes}

The oxygen isotopic composition has been analysed in hand-picked amethyst crystals from the thick sections used for fluid inclusion analyses (Table 4). The composition of the fluid in equilibrium with the quartz crystals has been calculated with the fractionation equilibrium equation of Sharp et al. [64], using the temperature from the fluid inclusion analyses. The estimated minimum trapping pressures calculated from the measured $\mathrm{T}_{\mathrm{h}}$ for the studied amethysts range between 0.01 and $0.03 \mathrm{kbar}$, which corresponds to paleo-depths up to $150 \mathrm{~m}$ under lithostatic conditions. Due to the shallow (epithermal) environment of amethyst formation, the pressure correction is likely to be $<10^{\circ} \mathrm{C}$ (e.g., Bodnar et al. [65]), thus not significantly affecting the calculation of $\delta^{18} \mathrm{O}$ values (see also discussion).

Table 4. Oxygen isotope compositions of amethyst quartz from various volcanic rocks in Greece $(\delta$ values in\% relative to Standard Mean Ocean Water (SMOW)). The oxygen isotope values in the fluid $\left(\delta^{18} \mathrm{O}_{\mathrm{Fl}}\right)$ in equilibrium with quartz have been calculated according to Sharp et al. [64], considering the range and average homogenization temperatures given by the fluid inclusions without any pressure correction.

\begin{tabular}{cccccc}
\hline Sample & Locality & $\boldsymbol{\delta}^{\mathbf{1 8}} \mathbf{O}_{\mathbf{Q t z}}$ & $\mathbf{T}_{\mathbf{h}}\left({ }^{\circ} \mathbf{C}\right)$ Range & $\boldsymbol{\delta}^{\mathbf{1 8}} \mathbf{O}_{\mathbf{F l}} \mathbf{m i n}$ & $\boldsymbol{\delta}^{\mathbf{1 8}} \mathbf{O}_{\mathbf{F l}} \mathbf{~ m a x}$ \\
\hline KS1 & Kassiteres & 10.5 & $211-275$ & -0.5 & 2.6 \\
SH2 & Sapes & 8.2 & $189-230$ & -4.3 & -1.7 \\
KIR1 & Kirki & 19.1 & - & - & - \\
SF2 & Kornofolia & 20.5 & $194-223$ & 8.4 & 10.2 \\
LS2 & Lesvos & 3.3 & $219-246$ & -7.3 & -5.8 \\
M1 & Milos & 14.1 & $193-219$ & 1.9 & 3.5 \\
M2 & Milos & 13.4 & $190-207$ & 1.0 & 2.1 \\
\hline
\end{tabular}

The studied amethysts yield isotopic $\delta^{18} \mathrm{O}$ values between 3.3 and $20.5 \%$ (Figure 8 ). Those from Kassiteres show a $\delta^{18} \mathrm{O}$ value of $10.5 \%$ and a range of values between -0.5 and $2.6 \%$ for the associated fluid at equilibrium at temperatures from 211 to $275{ }^{\circ} \mathrm{C}$, respectively. The Silver Hill amethyst at Sapes (north of Kassiteres), has a $\delta^{18} \mathrm{O}$ value of $8.2 \%$, while the values for the associated fluid at equilibrium range between -4.3 and -1.7 for temperatures between 189 and $230{ }^{\circ} \mathrm{C}$. The amethyst at Kornofolia, Evros district, yielded the highest $\delta^{18} \mathrm{O}$ values $(20.5 \%)$ ), corresponding to values from 8.4 to $10.2 \%$ for the associated fluid at temperatures between 189 and $230{ }^{\circ} \mathrm{C}$. The Lesvos amethyst has the lowest $\delta^{18} \mathrm{O}$ value of all amethysts analysed (3.3\%), which corresponds to values between -7.3 to $-5.8 \%$ for the associated fluid at temperatures from 219 to $246^{\circ} \mathrm{C}$. Finally, the two Milos amethyst samples have comparable $\delta^{18} \mathrm{O}$ values of 13.4 and $14.1 \%$ and display a range from 1.9 to $3.5 \%$ for the associated fluid at temperatures between $193-219{ }^{\circ} \mathrm{C}(\mathrm{M} 1)$, and from 1.0 to $2.1 \%$ for a fluid at $190-207^{\circ} \mathrm{C}(\mathrm{M} 2)$. 


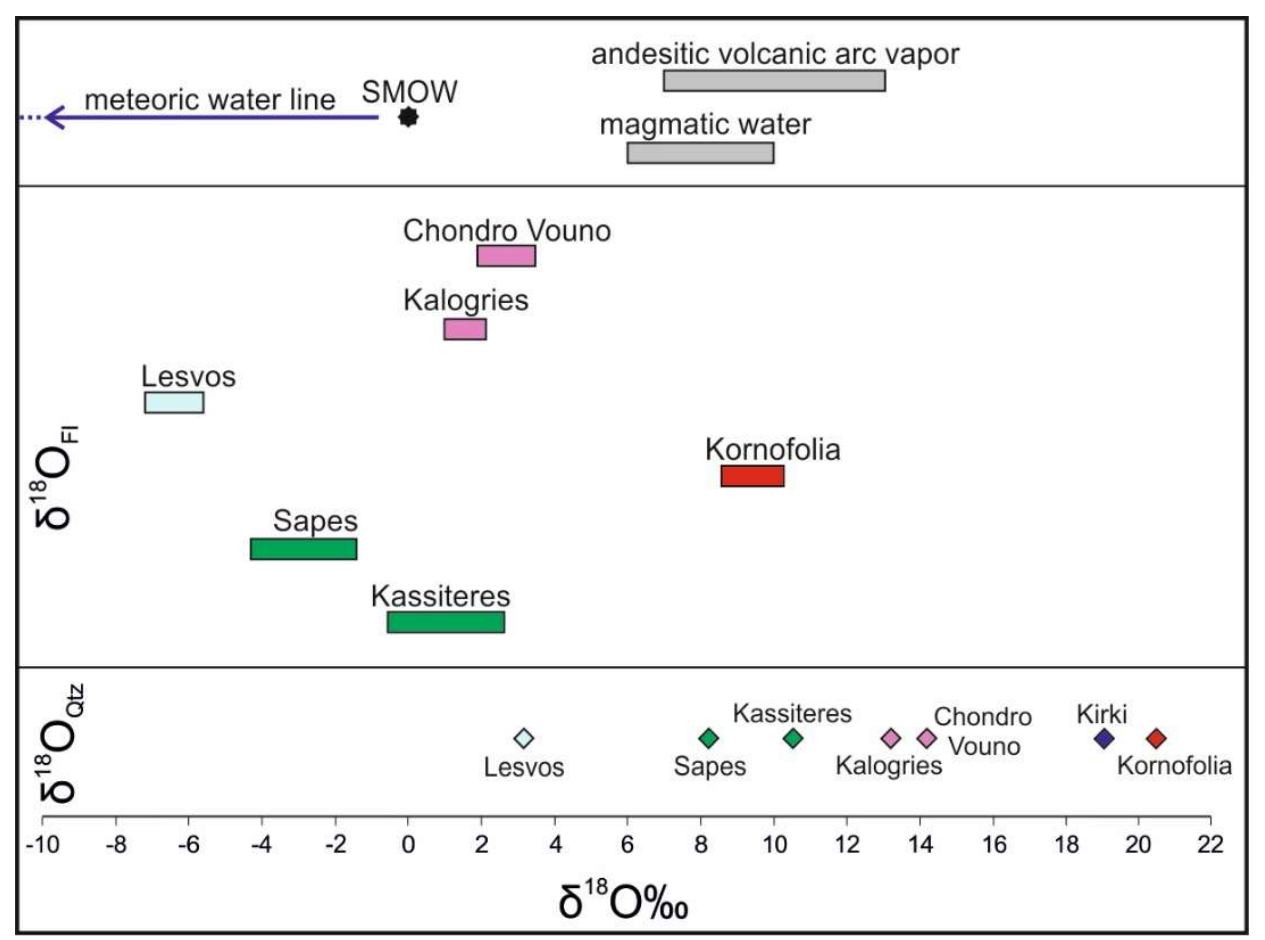

Figure 8. $\delta^{18} \mathrm{O}$ values of amethyst from volcanic rocks in Greece (diamonds). The minimum and maximum and average values of the associated fluid at equilibrium at the temperature ranges as well as average values estimated from fluid inclusion analyses are also shown. The values for magmatic water and andesitic volcanic arc vapor are from Taylor [66] and Giggenbach [67], respectively.

\section{Discussion}

Volcanic rocks host the majority of amethyst deposits worldwide. In Europe, famous amethyst localities are among others those of Idar-Oberstein, Baden-Baden and Chemnitz in Germany $[1,68]$, of Osilo in Sardinia (Italy) [1,69], of Přibram (Czech Republic) [1], Schemnitz and Kremnitz (Slovakia) [1], Roșia Montană, Săcărâmb, Baia Sprie and Cavnik (Romania) [1], and Madjarovo (Bulgaria) [1,8,70], all hosted in volcanic rocks of various ages from Paleozoic to Neogene. Quartz geodes in the basalts of Deccan, India [1], host amethyst associated with zeolites. Several amethyst localities in Japan are associated with epithermal $\mathrm{Cu}-\mathrm{Pb}-\mathrm{Zn}$ veins on Honshu Island [1]. Host-rocks for the amethyst in Brandberg (Namibia) [1,71], SW Nova Scotia, and Thunder Bay (Lake Superior, Canada) are silicified basalts $[1,7,8]$. Epithermal vein systems in Colorado, USA (Creede mining district and Cripple Creek) [72] and numerous similar occurrences in Mexico (e.g., at Guanajuato, Guerraro and Las Vigas districts) [1,73] are characterized by gem-quality amethyst crystals occurring mostly as the gangue of the veins and less common as typical geodes. Finally, huge amethyst geodes within basaltic lavas in Rio Grande do Sul, Brazil [74-80] and in Artigas, Uruguay [79,81-83] represent the most important resources of amethyst today. Amethyst crystallization conditions are still a matter of scientific debate. For the amethyst-bearing geodes in the basalts of Uruguay and Brazil, low temperatures of formation in the range from 50 to $120^{\circ} \mathrm{C}$ were estimated from fluid inclusion data $[74,75,82]$. However, earlier works in Brazilian amethyst indicated homogenization temperatures of 152 to $238{ }^{\circ} \mathrm{C}$ and salinity of 0.9 to $2.6 \mathrm{wt} \% \mathrm{NaCl}$ equiv and suggested a magmatic origin for the amethyst crystals [77].

Microthermometric data of the selected primary and pseudosecondary FIAs record the evolution of the hydrothermal fluids which were involved during amethyst formation. The plots of $T_{h}$ versus salinity of the fluid inclusion assemblages (Figure 9) are discussed for this reason and may be used for genetic interpretations. In the absence of evident boiling, the homogenization temperatures 
only yield a minimum estimate of the temperature during fluid entrapment. Although stratigraphic reconstruction in the various volcanic environments does not allow a precise determination of the depth of amethyst formation, it is assumed, based from previous information as presented in the regional geology chapter, that pressure correction is insignificant by comparison to other shallow environments (e.g., Bodnar et al. [65]). In this case, the measured $\mathrm{T}_{\mathrm{h}}$ corresponds to the temperature at which various parts of the amethysts grew. Accordingly, the homogenization temperatures of the studied amethysts are interpreted to be close to the formation temperatures.
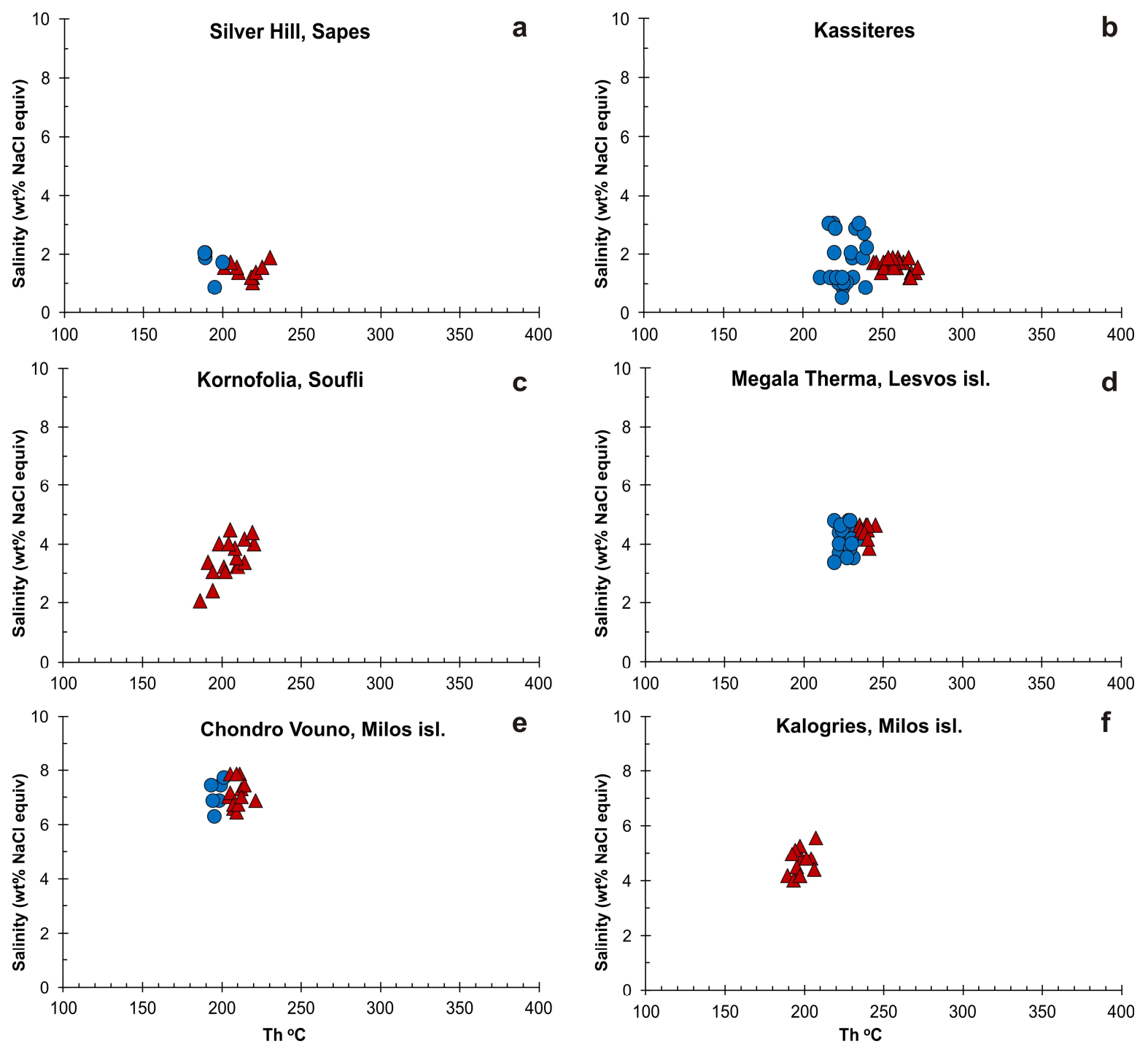

Figure 9. Homogenization temperatures versus salinity diagrams of fluid inclusions from various amethyst occurrences in volcanic rocks from Greece (a) Silver Hill from Sapes; (b) Kassiteres; (c) Kornofolia from Soufli; (d) Megala Therma from Lesvos island; (e) Chondro Vouno and (f) Kalogries from Milos island. Red triangles represent FIAs with higher $T_{h}$ at the external parts of the amethysts and blue circles correspond to FIAs with the lower $\mathrm{T}_{\mathrm{h}}$ at the inner crystal parts.

In the cases of Silver Hill in Sapes and Kassiteres, the evolution of the fluids show two different groups, the high $T_{h}$ and the low $T_{h}$ (Figure 9a,b) which demonstrates obvious cooling of the hydrothermal fluids during the formation of the amethyst. In Silver Hill, the low salinity fluid ( 0.9 to $2.1 \mathrm{wt} \% \mathrm{NaCl}$ equiv) evolved from higher temperatures $\left(230-201{ }^{\circ} \mathrm{C}\right.$ ) of the older amethyst close to the vein walls to lower temperatures $\left(203-189^{\circ} \mathrm{C}\right)$ for the younger amethyst at the centre of 
the banded veins, confirming previous results of Melfos [12]. The same situation is observed for the amethysts from Kassiteres where the majority of the FIAs homogenized at temperatures between 211 and $270{ }^{\circ} \mathrm{C}$, reflecting gradual cooling of the fluid from the external with higher $\mathrm{T}_{\mathrm{h}}\left(275-238^{\circ} \mathrm{C}\right)$ to the inner parts of the veins with lower $\mathrm{T}_{\mathrm{h}}\left(239-211^{\circ} \mathrm{C}\right)$ and variable salinities.

The observed minor increase of salinity and decrease of temperature, especially in Kassiteres, is possibly associated with boiling in open system with steam loss $[38,84]$. Boiling produces large quantities of vapour and, in open systems, causes loss of $\mathrm{H}_{2} \mathrm{O}$ and other volatile species. This mechanism results to the partitioning of salts into the liquid phase and the residual liquid becomes more saline with a gradually decreasing temperature $[84,85]$. However, boiling was not confirmed by the presence of vapour-rich fluid inclusions at FIAs in any of these two amethyst occurrences, although boiling processes could be responsible for the crystallization of amethyst together with adularia at Sapes and Kassiteres $[38,86,87]$. Calcite accompanying amethyst at Kirki has a platy habit, indicating that its deposition probably took place from boiling hydrothermal fluids (according to Simmons and Browne [86] and Simmons et al. [87]).

The trends of the fluid inclusions in amethysts from Kornofolia, Megala Therma, Chondro Vouno and Kalogries from higher to lower temperatures and salinities (Figure 9c-f) may indicate a dilution process due to mixing of moderately saline hydrothermal fluids with low temperature-low salinity fluids having roughly similar temperatures, as it is described by Hedenquist [88]. Since no evidence of phase separation, such as boiling assemblages or vapour-rich inclusions were observed, the "mixing" hypothesis is preferred, although "gentle boiling", such as described in Moncada et al. [89], cannot be fully excluded.

Fluid inclusions have been studied previously in the epithermal systems of Milos Island. The Profitis Ilias epithermal gold mineralization was formed at temperatures from 200 to $250{ }^{\circ} \mathrm{C}$ by fluids with diverse salinity (3-15 wt $\% \mathrm{NaCl}$ equiv) under boiling conditions [90]. Fluid inclusion data in quartz from the Vani Mn deposit (about $1 \mathrm{~km} \mathrm{NE}$ of Kalogries) and the Chondro Vouno Au-Ag deposit in Kilias et al. [90,91] and Naden et al. [92], show temperatures in the range of about 100 to $230{ }^{\circ} \mathrm{C}$, boiling conditions, and involvement of seawater in addition to meteoric water for quartz deposition. Salinity in both areas shows a wide range from 0.1 to $17 \mathrm{wt} \% \mathrm{NaCl}$ equiv and is best explained by boiling phenomena. Similarly, Smith et al. [93] suggested a fluid with increasing salinity (3-8 wt \% NaCl equiv) and decreasing temperature $180-220^{\circ} \mathrm{C}$ for the Triades deposit (lying between Chrondro Vouno and Kalogries), indicating an extensive boiling system. Homogenization temperatures of fluid inclusions in barite from Triades showed homogenization temperatures between 280 and $340{ }^{\circ} \mathrm{C}$ and low salinity from 2.14 to $5.62 \mathrm{wt} \% \mathrm{NaCl}$ equiv [94], although the high temperatures could be attributed to leakage or stretching of the fluids during post-entrapment reequilibration.

Comparing the distribution of $\mathrm{T}_{\mathrm{h}}\left(193-221^{\circ} \mathrm{C}\right)$ and salinity $(6.3$ to $7.9 \mathrm{wt} \% \mathrm{NaCl}$ equiv) of the studied amethysts in Chondro Vouno with the adjacent epithermal system of Profitis Ilias we can also assume by analogy a boiling system for the formation of amethyst. Similarly, at the Kalogries amethysts, the distribution of $\mathrm{T}_{\mathrm{h}}\left(190-207^{\circ} \mathrm{C}\right)$ and salinity $(4.0-5.6 \mathrm{wt} \% \mathrm{NaCl}$ equiv) are comparable with the nearby Vani Mn deposit where Kilias et al. [91], consider extreme boiling of seawater and mixing either with condensed boiled-off vapor or heated meteoric water to be the major control on mineralization. Alfieris et al. [31] also confirm the role of the vapor phase in the intermediate- to high-sulfidation state fluids under boiling conditions for the epithermal systems on Milos Island. Salinity variations can therefore be produced by continuous boiling mainly in restricted fractures [84] or by fluid mixing.

Homogenization temperatures and salinity measured here for amethyst from the intermediate-sulfidation epithermal deposits at Silver Hill and Kassiteres (Sapes area), Megala Therma (Lesvos Island) and Chondro Vouno (Milos Island) are in the range of the values obtained from other similar deposits like, for example, the Madjarovo ore field in Eastern Rhodope, Bulgaria, and the Amethyst vein system at Creede mining district, Colorado. At Madjarovo, amethyst crystallized from low salinity fluids (2.0-6.9 $\mathrm{wt} \% \mathrm{NaCl}$ equiv) in the range $160-240{ }^{\circ} \mathrm{C}$ [70]. At Creede, average 
homogenization temperatures and salinity in amethyst decrease from lower to upper levels of the mine, from an average $\mathrm{T}_{\mathrm{h}}=238{ }^{\circ} \mathrm{C}$ and an average salinity of $9.8 \mathrm{wt} \% \mathrm{NaCl}$ equiv to $\mathrm{T}_{\mathrm{h}}=170{ }^{\circ} \mathrm{C}$ and an average salinity of $6.5 \mathrm{wt} \% \mathrm{NaCl}$ equiv. The decrease in temperature and dilution of hydrothermal solutions were interpreted as a result of mixing with near-surface waters [72]. Stable isotope data revealed significant $\delta^{18} \mathrm{O}$ variations in the studied amethyst. In general, most $\delta^{18} \mathrm{O}$ values correspond to a mixing of magmatic and oceanic (and/or meteoric) water, with the highest magmatic component in Komofolia and the lowest in Lesvos.

The studied amethysts are genetically related to the development of epithermal systems, during the waning stages of Oligocene to Pleistocene volcanic activity. All the studied amethyst occurrences are related to intermediate- to low-sulfidation epithermal veins with well-developed hydrothermal alteration zoning (e.g., silicic alteration grading outward to adularia and/or sericitic alteration, then to argillic-, propylitic-, zeolitic alteration and finally to fresh volcanic rock).

Amethyst occurs in quartz veins crosscutting all the above alteration zones. The mineralogical data presented in this study are in accordance with those obtained through fluid inclusion measurements and may further be used to estimate the crystallization conditions of the studied amethyst. In Kirki, the coexistence of laumontite, analcime, heulandite and smectite indicate temperatures of about $175^{\circ} \mathrm{C}$. Similar temperatures of formation can be assumed through the coexistence of heulandite and clinoptilolite accompanying amethyst in Kornofolia. Application of the chlorite geothermometer after Cathelineau [95], suggests temperatures of amethyst formation for Megala Therma, Lesvos Island, from 223 to $234{ }^{\circ} \mathrm{C}$. Mineralogical and geological information indicate that amethyst formation took place mainly from near neutral to alkaline fluids and in the stability field of adularia, calcite, chlorite and zeolites.

It is generally accepted that amethyst is formed through a process involving irradiation in which $\mathrm{Fe}^{3+}$ loses and electron and gives rise to a new color center, $\mathrm{Fe}^{4+}$, which is responsible for its violet color [2]. Amethyst requires oxidizing conditions to incorporate $\mathrm{Fe}^{3+}$ and these may result from mixing of oxidized meteoric and/or seawater with upwelling hydrothermal fluids [96]. Natural radiation can probably be explained by the moderate $U$ concentrations of the surrounding volcanic host rocks. Shallow submarine conditions are most likely to have prevailed in all areas, contributing sea- and meteoric water to the hydrothermal fluids, Sapes being probably under subaerial conditions.

\section{Conclusions}

Epithermally altered volcanic rocks in Greece host amethyst veins in association with various amounts of adularia, calcite, smectite, chlorite, sericite, pyrite, zeolites (laumontite, heulandite, clinoptilolite), analcime, barite, fluorite and goethite/lepidocrocite in the veins. Host rocks are Oligocene to Pleistocene lavas and pyroclastics of intermediate- to acidic composition and with a calc-alkaline to shoshonitic affinity. Precipitation of amethyst took place during the final stages of the magmatic-hydrothermal activity in the areas from near-neutral to alkaline fluids. The present study shows that the amethysts from six volcanogenic environments in Greece with diverse ages but similar geotectonic regimes with post-subduction extensional magmatism were formed by hydrothermal fluids with relatively low temperatures $\left(\sim 200-250{ }^{\circ} \mathrm{C}\right)$ and low to moderate salinity $(1-8 \mathrm{wt} \% \mathrm{NaCl}$ equiv). A genetic mechanism with a gradually cooling fluid from the external to the inner parts of the veins, possibly with subsequent boiling in an open system, is considered for the amethysts of Silver Hill in Sapes and of Kassiteres. Amethysts from Kornofolia, Megala Therma, Chondro Vouno and Kalogries were formed by mixing of moderately saline hydrothermal fluids with low-salinity fluids at relatively lower temperatures $\left(\sim 200{ }^{\circ} \mathrm{C}\right.$ for Kornofolia, Chondro Vouno and Kalogries, and $\sim 250{ }^{\circ} \mathrm{C}$ for Megala Therma), indicating the presence of dilution processes, although boiling in an open system is not to be excluded. Stable isotope studies revealed a mixing between magmatic and marine (and/or meteoric) waters for most of the samples. A major contribution of magmatic water is only evidenced for the Kornofolia amethyst. The oxidizing conditions required for the amethyst formation were probably the result of mixing between meteoric or seawater with upwelling hydrothermal fluids. 
Ongoing geological and gemological work aims to investigate if the volcanic-hosted amethyst in Greece is of gemstone quality and to evaluate their potential for future exploitation.

Author Contributions: P.V. collected the studied samples. P.V. assisted by C.M., V. M., D.A. and I.P. evaluated the mineralogical and geochemical data. V.M. and P.V. conducted the fluid inclusion measurements, and evaluated them with A.T. A.T., J.G. and P.V. evaluated the isotopic data. P.V. and V.M. wrote the manuscript.

Acknowledgments: Authors would like to thank Evangelos Michailidis for their kind help on microanalyses in the University of Athens. Two anonymous reviewers are especially thanked for their constructive comments that greatly improved the manuscript.

Conflicts of Interest: The authors declare no conflict of interest.

\section{References}

1. Lieber, W. Amethyst: Geschichte, Eigenschaften, Fundorte; Christian Weise Verlag: München, Germany, 1994; 188p.

2. Rossman, G.R. Colored varieties of the silica minerals. Rev. Mineral. 1994, 29, 433-467.

3. Cox, R.T. Optical absorption of the $\mathrm{d}^{4}$ ion $\mathrm{Fe}^{4+}$ in pleochroic amethyst quartz. J. Phys. C Solid State Phys. 1977, 10, 4631-4643. [CrossRef]

4. Fritsch, E.; Rossman, G.R. An update of colors in gems part 2: Colors involving multiple atoms and color centers. Gems Gemol. 1988, 24, 3-15. [CrossRef]

5. Cohen, A.J. Amethyst color in quartz, the result of radiation protection involving iron. Am. Mineral. 1985, 70, 1180-1185.

6. Scholz, R.; Chaves, M.L.S.C.; Krambrock, K.; Pinheiro, V.B.; Barreto, S.B.; de Menezes, M.G. Brazilian quartz deposits with special emphasis on gemstone quartz and its color treatment. In Quartz: Deposits, Mineralogy and Analytics; Götze, J., Möckel, R., Eds.; Springer: Berlin/Heidelberg, Germany, 2012; pp. 139-159.

7. Wilson, B.S. Colored gemstones from Canada. In Geology of Gem Deposits; Groat, L.A., Ed.; Mineralogical Association of Canada Short Course; Mineralogical Association of Canada: Québec, QC, Canada, 2007; Volume 37, pp. 255-270.

8. Kievlenko, E.Y. Geology of Gems; Ocean Pictures Ltd.: Romsey, UK, 2003; 468p.

9. Götze, J. Chemistry, textures and physical properties of quartz-Geological interpretation and technical application. Mineral. Mag. 2009, 73, 645-671. [CrossRef]

10. Götze, J.; Möckel, R. Quartz: Deposits, Mineralogy and Analytics; Springer: Berlin/Heidelberg, Germany, 2012.

11. Voudouris, P.; Katerinopoulos, A. New occurrences of mineral megacrysts in Tertiary magmatic-hydrothermal and epithermal environments in Greece. Doc. Nat. 2004, 151, 1-21.

12. Melfos, V. Study of fluid inclusions in amethysts from areas of Macedonia and Thrace: Sapes, Soufli, Nevrokopi. In Proceedings of the 2nd Congress of the Economic Geology Committee, Mineralogy \& Petrology (GSG), Thessaloniki, Greece, 7-9 October 2005; pp. 219-228. (In Greek)

13. Maneta, V.; Voudouris, P. Quartz megacrysts in Greece: Mineralogy and environment of formation. Bull. Geol. Soc. Greece 2010, 43, 685-696. [CrossRef]

14. Voudouris, P.; Katerinopoulos, A.; Melfos, V. Alpine-type fissure minerals in Greece. Doc. Nat. 2004, 151, 23-45.

15. Voudouris, P.; Psimis, I.; Mavrogonatos, C.; Kanellopoulos, C.; Kati, M.; Chlekou, E. Amethyst occurrences in Tertiary volcanic rocks of Greece: Mineralogical and genetic implications. Bull. Geol. Soc. Greece 2013, 47, 477-486. [CrossRef]

16. Driesner, T.; Heinrich, C.A. The system $\mathrm{H}_{2} \mathrm{O}-\mathrm{NaCl}$. I. Correlations for molar volume, enthalpy, and isobaric heat capacity from 0 to 1000 degrees C, 1 to 5000 bar, and 0 to 1 X-NaCl. Geochim. Cosmochim. Acta 2007, 71, 4880-4901. [CrossRef]

17. Bodnar, R.J. Revised equation and table for determining the freezing point depression of $\mathrm{H}_{2} \mathrm{O}-\mathrm{NaCl}$ solutions. Geochim. Cosmochim. Acta 1993, 57, 683-684. [CrossRef]

18. Mattey, D.P. LaserPrep: An Automatic Laser-Fluorination System for Micromass 'Optima' or 'Prism' Mass Spectrometers. Micromass Appl. Note 1997, 207, 8.

19. Jolivet, L.; Brun, J.P. Cenozoic geodynamic evolution of the Aegean region. Int. J. Earth Sci. 2010, 99, $109-138$. [CrossRef] 
20. Kydonakis, K.; Brun, J.-P.; Sokoutis, D.; Gueydan, F. Kinematics of Cretaceous subduction and exhumation in the western Rhodope (Chalkidiki block). Tectonophysics 2015, 665, 218-235. [CrossRef]

21. Menant, A.; Jolivet, L.; Tuduri, J.; Loiselet, C.; Bertrand, G.; Guillou-Frottier, L. 3D subduction dynamics: A first-order parameter of the transition from copper- to gold-rich deposits in the eastern Mediterranean region. Ore Geol. Rev. 2018, 94, 118-135. [CrossRef]

22. Fytikas, M.; Innocenti, F.; Manneti, P.; Mazzuoli, R.; Peccerillo, A.; Villari, L. Tertiary to Quaternary evolution of volcanism in the Aegean region. In The Geological Evolution of the Eastern Mediterranean; Dixon, J.E., Robertson, A.H.F., Eds.; Geological Society Special Publication: Oxford, UK, 1984; Volume 17, pp. 687-699.

23. Innocenti, F.; Kolios, N.; Manetti, O.; Mazzuoli, R.; Peccerillo, G.; Rita, F.; Villari, L. Evolution and geodynamic significance of the Tertiary orogenic volcanism in northeastern Greece. Bull. Volcanol. 1984, 47, 25-37. [CrossRef]

24. Christofides, G.; Pecskay, Z.; Soldatos, T.; Eleftheriadis, G.; Koroneos, A. The Tertiary Evros volcanic rocks (Greece): Petrology, K/Ar geochronology and volcanism evolution. Geol. Carpath. 2004, 55, 397-409.

25. Marchev, P.; Kaiser-Rohrmeier, M.; Heinrich, C.; Ovtcharova, M.; von Quadt, A.; Raicheva, R. Hydrothermal ore deposits related to post-orogenic extensional magmatism and core complex formation: The Rhodope Massif of Bulgaria and Greece. Ore Geol. Rev. 2005, 27, 53-89. [CrossRef]

26. Melfos, V.; Voudouris, P. Cenozoic metallogeny of Greece and potential for precious, critical and rare metals exploration. Ore Geol. Rev. 2017, 59, 1030-1057. [CrossRef]

27. Pe-Piper, G.; Piper, D.J.W. The Igneous Rocks of Greece: The Anatomy of an Orogen; Gebruder Borntraeger: Berlin, Germany, 2002; Volume 30.

28. Ottens, B.; Voudouris, P. Griechenland: Mineralien-Fundorte-Lagerstätten; Christian Weise Verlag: München, Germany, 2018; in press.

29. Fytikas, M.; Innocenti, F.; Kolios, N.; Manneti, P.; Mazzuoli, R.; Poli, G.; Rita, F.; Villari, L. Volcanology and petrology of volcanic products from the island of Milos and neighboring islets. J. Volcanol. Geotherm. Res. 1986, 28, 297-317. [CrossRef]

30. Stewart, A.L.; McPhie, J. Facies architecture and Late Pliocene-Pleistocene evolution of a felsic volcanic island, Milos, Greece. Bull. Volcanol. 2006, 68, 703-726. [CrossRef]

31. Alfieris, D.; Voudouris, P.; Spry, P.G. Shallow submarine epithermal Pb-Zn-Cu-Au-Ag-Te mineralization on western Milos Island, Aegean Volcanic Arc, Greece: Mineralogical, Geological and Geochemical constraints. Ore Geol. Rev. 2013, 53, 159-180. [CrossRef]

32. Peccerillo, A.; Taylor, S.R. Geochemistry of Eocene calc-alkaline volcanic rocks from the Kastamonu area, northern Turkey. Contr. Mineral. Petrol. 1976, 58, 63-81. [CrossRef]

33. Le Bas, M.J.; Le Maitre, R.W.; Streckeisen, A.; Zanettin, B. A chemical classification of volcanic rocks based on total alkali-silica diagram. J. Petrol. 1986, 27, 745-750. [CrossRef]

34. Irvine, T.N.; Baragar, W.R.W. A guide to chemical classification of the common volcanic rocks. Can. J. Earth Sci. 1971, 8, 523-548.

35. Miyashiro, A. Volcanic Rock Series in Island Arcs and Active Continental Margins. Am. J. Sci. 1974, 274, 321-355. [CrossRef]

36. Shand, S.J. The Eruptive Rocks, 2nd ed.; John Wiley: New York, NY, USA, 1943.

37. Liakopoulos, A. Hydrothermalisme et Minéralisations Métallifères de l' île de Milos (Cyclades, Grèce). Ph.D. Thesis, Université Pierre et Marie Curie, Paris, France, 1987.

38. Voudouris, P. Mineralogical, Geochemical and Fluid Inclusion Studies on Epithermal Vein Type Gold/Silver Mineralizations at Kassiteres/Sapes, (NE-Greece). Ph.D. Thesis, University of Hamburg, Hamburg, Germany, 1993.

39. Voudouris, P. The minerals of Eastern Macedonia and Western Thrace: Geological framework and environment of formation. Bull. Geol. Soc. Greece 2005, 37, 62-77.

40. Shawh, A.J.; Constantinides, D.C. The Sappes gold project. Bull. Geol. Soc. Greece 2001, 34, $1073-1080$. [CrossRef]

41. Voudouris, P.; Velitzelos, D.; Velitzelos, E.; Thewald, U. Petrified wood occurrences in western Thrace and Limnos island: Mineralogy, geochemistry and depositional environment. Bull. Geol. Soc. Greece 2007, 40, 238-250. [CrossRef] 
42. Voudouris, P.; Alfieris, D. New porphyry-Cu \pm Mo occurrences in northeastern Aegean/Greece: Ore mineralogy and transition to epithermal environment. In Mineral Deposit Research: Meeting the Global Challenge; Mao, J., Bierlein, F.P., Eds.; Springer: Berlin, Germany, 2005; pp. 473-476.

43. Alfieris, D. Geological, Geochemical and Mineralogical Studies of Shallow Submarine Epithermal Mineralization in an Emergent Volcanic Edifice, at Western Milos Island, Greece. Ph.D. Thesis, University of Hamburg, Hamburg, Germany, 2006.

44. Coffey, J. The Stratigraphy and Palaeontology of Cape Vani, Milos, Greece; Honours Research Report; School of Earth Sciences, University of Melbourne: Parkville, VIC, Australia, 2005.

45. Hey, M.H. A new review of the chlorites. Mineral. Mag. 1954, 30, 277-292. [CrossRef]

46. Coombs, D.S.; Alberti, A.; Armbruster, T.; Artioli, G.; Colella, C.; Galli, E.; Grice, J.D.; Liebau, F.; Mandarino, J.A.; Minato, H.; et al. Recommended nomenclature for zeolite minerals: Report of the Subcommittee on Zeolites of the Mineralogical Association, Commission on New Minerals and Mineral Names. Eur. J. Mineral. 1998, 10, 1037-1081. [CrossRef]

47. Larsen, A.O.; Nordrum, F.S.; Döbelin, N.; Armbruster, T.; Petersen, O.V.; Erambert, M. Heulandite-Ba, a new zeolite species from Norway. Eur. J. Mineral. 2005, 17, 143-153. [CrossRef]

48. Voudouris, P.; Maneta, V. Quartz in Greece; CreateSpace Publ. and Amazon.com, Inc.: Seattle, WA, USA, 2017. (In Greek)

49. Roedder, E. Fluid inclusions. In Reviews in Mineralogy; Mineralogical Society of America: Chantilly, VA, USA, 1984; Volume 12, p. 644.

50. Van den Kerkhof, A.M.; Hein, U.F. Fluid inclusion petrography. Lithos 2001, 55, 27-47. [CrossRef]

51. Goldstein, R.H.; Reynolds, T.J. Systematics of Fluid Inclusions in Diagenetic Minerals; SEPM Short Course; Society for Sedimentary Geology: Broken Arrow, OK, USA, 1994; Volume 31.

52. Audétat, A.; Günther, D. Mobility and $\mathrm{H}_{2} \mathrm{O}$ loss from fluid inclusions in natural quartz crystals. Contrib. Mineral. Petrol. 1999, 137, 1-14. [CrossRef]

53. Tarantola, A.; Diamond, L.W.; Stünitz, H. Modification of fluid inclusions in quartz by deviatoric stress I: Experimentally induced changes in inclusion shapes and microstructures. Contrib. Mineral. Petrol. 2010, 160, 825-843. [CrossRef]

54. Tarantola, A.; Diamond, L.W.; Stünitz, H.; Thust, A.; Pec, M. Modification of fluid inclusions in quartz by deviatoric stress III: Influence of principal stresses on inclusion density and orientation. Contrib. Mineral. Petrol. 2012, 164, 537-550. [CrossRef]

55. Diamond, L.W.; Tarantola, A. Interpretation of fluid inclusions in quartz deformed by weak ductile shearing: Reconstruction of differential stress magnitudes and pre-deformation fluid properties. Earth Planet. Sci. Lett. 2015, 417, 107-119. [CrossRef]

56. Stünitz, H.; Thust, A.; Heilbronner, R.; Behrens, H.; Kilian, R.; Tarantola, A.; Fitz Gerald, J.D. Water redistribution in experimentally deformed natural milky quartz single crystals-Implications for $\mathrm{H}_{2} \mathrm{O}$-weakening processes. J. Geophys. Res. Solid Earth 2017, 122, 866-894. [CrossRef]

57. Bakker, R.J.; Jansen, J.B.H. Preferential water leakage from fluid inclusions by means of mobile dislocations. Nature 1990, 345, 58-60. [CrossRef]

58. Bakker, R.J.; Jansen, J.B.H. A mechanism for preferential $\mathrm{H}_{2} \mathrm{O}$ leakage from fluid inclusions in quartz, based on TEM observations. Contrib. Mineral. Petrol. 1994, 116, 7-20. [CrossRef]

59. Goldstein, R.H. Fluid inclusions: Analysis and interpretation. In Fluid Inclusions: Analysis and Interpretation; Samson, I.M., Anderson, A.J., Marshall, D.D., Eds.; SEPM Short Course; Society for Sedimentary Geology: Broken Arrow, OK, USA, 2003; Volume 32, pp. 9-53.

60. Shepherd, T.; Rankin, A.; Alderton, D. A Practical Guide to Fluid Inclusion Studies; Blackie and Son: Glasgow, UK, 1985.

61. Bodnar, R.J. Introduction to fluid inclusions. In Fluid Inclusions: Analysis and Interpretation; Samson, I.M., Anderson, A.J., Marshall, D.D., Eds.; SEPM Short Course; Society for Sedimentary Geology: Broken Arrow, OK, USA, 2003; Volume 32, pp. 1-8.

62. Sterner, S.M.; Bodnar, R.J. Synthetic fluid inclusions-VII. Re-equilibration of fluid inclusions in quartz during laboratory-simulated metamorphic burial and uplift. J. Metamorph. Geol. 1989, 7, 243-260. [CrossRef]

63. Sterner, S.M.; Hall, D.L.; Keppler, H. Compositional re-equilibration of fluid inclusions in quartz. Contrib. Mineral. Petrol. 1995, 119, 1-15. [CrossRef] 
64. Sharp, Z.D.; Gibbons, J.A.; Maltsev, O.; Atudorei, V.; Pack, A.; Sengupta, S.; Shock, E.L.; Knauth, L.P. A calibration of the triple oxygen isotope fractionation in the $\mathrm{SiO}_{2}-\mathrm{H}_{2} \mathrm{O}$ system and applications to natural samples. Geochim. Cosmochim. Acta 2016, 186, 105-119. [CrossRef]

65. Bodnar, R.J.; Reynolds, T.J.; Kuehn, C.A. Fluid-Inclusion systematics in epithermal systems. Rev. Econ. Geol. 1985, 2, 73-97.

66. Taylor, H.P., Jr. Oxygen and hydrogen isotope relationships in hydrothermal mineral deposits. In Geochemistry of Hydrothermal Ore Deposits, 2nd ed.; Barnes, H.L., Ed.; Wiley: New York, NY, USA, 1979; pp. 236-318.

67. Giggenbach, W.F. The origin and evolution of fluids in magmatic-hydrothermal systems. In Geochemistry of Hydrothermal Ore Deposits, 3nd ed.; Barnes, H.L., Ed.; Wiley: New York, NY, USA, 1997; pp. 737-796.

68. Ettig, F. Sachsischer Amethyst. Aufschluss 1952, 3, 52-53.

69. Bringe, H.H.; Grubessi, O. Amethyst und Yugawaralith von Osilo. Aufschluss 1982, 33, 41-44.

70. Breskovska, V.; Tarkian, M. Mineralogy and Fluid Inclusion Study of Polymetallic Veins in the Madjarovo Ore Field, Eastern Rhodope, Bulgaria. Mineral. Petrol. 1993, 49, 103-118. [CrossRef]

71. Henn, J.; Lieber, W. Amethyst von Brandberg, Namibia. Lapis 1993, 18, 44-48.

72. Robinson, R.W.; Norman, D.I. Mineralogy and Fluid Inclusion Study of the Southern Amethyst Vein System, Creede Mining District, Colorado. Econ. Geol. 1984, 79, 439-447. [CrossRef]

73. Wallace, T. Die violetten Schätze von Guerrero und Veracruz, Mexico. Extra Lapis 2015, 49, 80-99.

74. Gilg, H.A.; Morteani, G.; Kostitsyn, Y.; Preinfalk, C.; Gatter, I.; Strieder, A.J. Genesis of amethyst geodes in basaltic rocks of the Serra Geral Formation (Ametista do Sul, Rio Grande do Sul, Brazil): A fluid inclusion, REE, oxygen, carbon, and Sr isotope study on basalt, quartz, and calcite. Miner. Depos. 2003, 38, 1009-1025. [CrossRef]

75. Gilg, H.A.; Krüger, Y.; Taubald, H.; van den Kerkhof, A.M.; Frenz, M.; Morteani, M. Mineralisation of amethyst-bearing geodes in Ametista do Sul (Brazil) from low-temperature sedimentary brines: Evidence from monophase liquid inclusions and stable isotopes. Miner. Depos. 2014, 49, 861-877. [CrossRef]

76. Proust, D.; Fontaine, C. Amethyst-bearing lava flows in the Paraná Basin (Rio Grande do Sul, Brazil): Cooling, vesiculation and formation of the geodic cavities. Geol. Mag. 2007, 144, 53-65. [CrossRef]

77. Proust, D.; Fontaine, C. Amethyst geodes in the basaltic flow from Triz quarry at Ametista do Sul (Rio Grande do Sul, Brazil): Magmatic source of silica for the amethyst crystallizations. Geol. Mag. 2007, 144, 731-740. [CrossRef]

78. Commin-Fischer, A.; Berger, G.; Polvé, M.; Dubois, M.; Sardini, P.; Beaufort, D.; Formoso, M. Petrography and chemistry of $\mathrm{SiO}_{2}$ filling phases in the amethyst geodes from the Serra Geral Formation deposit, Rio Grande do Sul, Brazil. J. South Am. Earth Sci. 2010, 29, 751-760. [CrossRef]

79. Hartmann, L.A.; da Cunha Duarte, L.; Massonne, H.J.; Michelin, C.; Rosenstengel, L.M.; Bergmann, M.; Theye, T.; Pertille, J.; Arena, K.R.; Duarte, S.K. Sequential opening and filling of cavities forming vesicles, amygdales and giant amethyst geodes in lavas from the southern Paraná volcanic province, Brazil and Uruguay. Int. Geol. Rev. 2012, 54, 1-14. [CrossRef]

80. Hartmann, L.A.; Antunes, L.M.; Rosenstengel, L.M. Stratigraphy of amethyst geode-bearing lavas and fault-block structures of the Entre Rios mining district, Paraná volcanic province, southern Brazil. Ann. Braz. Acad. Sci. 2014, 86, 187-198. [CrossRef]

81. Duarte, L.C.; Hartmann, L.A.; Vasconcellos, M.A.Z.; Medeiros, J.T.N.; Theye, T. Epigenetic formation of amethyst-bearing geodes from Los Catalanes gemological district, Artigas, Uruguay, southern Paraná Magmatic Province. J. Volcanol. Geotherm. Res. 2009, 184, 427-436. [CrossRef]

82. Morteani, G.; Kostitsyn, Y.; Preinfalk, C.; Gilg, H.A. The genesis of the amethyst geodes at Artigas (Uruguay) and the paleohydrology of the Guarani aquifer: Structural, geochemical, oxygen, carbon, strontium isotope and fluid inclusion study. Int. J. Earth Sci. 2010, 99, 927-947. [CrossRef]

83. Duarte, L.C.; Hartmann, L.A.; Ronchi, L.H.; Berner, Z.; Theye, T.; Massonne, H.J. Stable isotope and mineralogical investigation of the genesis of amethyst geodes in the Los Catalanes gemological district, Uruguay, southernmost Parana volcanic province. Miner. Depos. 2011, 46, 239-255. [CrossRef]

84. Wilkinson, J.J. Fluid inclusions in hydrothermal ore deposits. Lithos 2001, 55, 229-272. [CrossRef]

85. Hedenquist, J.W.; Henley, R.W. The importance of $\mathrm{CO}_{2}$ on freezing point measurements of fluid inclusions; evidence from active geothermal systems and implications for epithermal ore deposition. Econ. Geol. 1985, 80, 1379-1406. [CrossRef] 
86. Simmons, S.F.; Browne, P.R.L. Hydrothermal minerals and precious metals in the Broadlands-Ohaaki geothermal system: Implications for understanding low-sulfidation epithermal environments. Econ. Geol. 2001, 95, 971-999. [CrossRef]

87. Simmons, S.F.; White, N.W.; John, D.A. Geological characteristics of epithermal precious and base metal deposits. Econ. Geol. 2005, 100, 485-522.

88. Hedenquist, J.W. Boiling and dilution in the shallow portion of the Waiotapu geothermal system, New Zealand. Geochim. Cosmochim. Acta 1991, 55, 2753-2765. [CrossRef]

89. Moncada, D.; Mutchler, S.; Nieto, A.; Reynolds, T.J.; Rimstidt, J.D.; Bodnar, R.J. Mineral textures and fluid inclusion petrography of the epithermal Ag-Au deposits at Guanajuato, Mexico: Application to exploration. J. Geochem. Explor. 2012, 114, 20-35. [CrossRef]

90. Kilias, S.P.; Naden, J.; Cheliotis, I.; Shepherd, T.J.; Constandinidou, H.; Crossing, J.; Simos, I. Epithermal gold mineralisation in the active Aegean volcanic arc: The Profitis Ilias deposit, Milos island, Greece. Miner. Depos. 2001, 36, 32-44. [CrossRef]

91. Kilias, S.P.; Detsi, K.; Godelitsas, A.; Typas, M.; Naden, J.; Marantos, Y. Evidence of Mn-oxide biomineralization, Vani Mn deposit, Milos, Greece. In Digging Deeper, Proceedings of the Ninth Biennial Meeting of the Society for Geology Applied to Mineral Deposits, Dublin, Ireland 20-23 August 2007; Irish Association of Economic Geologists: Dublin, Ireland, 2007; pp. 1069-1072.

92. Naden, J.; Kilias, S.P.; Darbyshire, D.B.F. Active geothermal systems with entrained seawater as analogues for transitional continental magmato-hydrothermal and volcanic-hosted massive sulfide mineralization-the example of Milos Island, Greece. Geology 2005, 33, 541-544. [CrossRef]

93. Smith, D.J.; Naden, J.; Miles, A.J.; Bennett, H.; Bicknell, S.H. Mass wasting events and their impact on the formation and preservation of submarine ore deposits. Ore Geol. Rev. 2018, 97, 143-151. [CrossRef]

94. Vavelidis, M.; Melfos, V. Fluid inclusion evidence for the origin of the barite silver-gold-bearing $\mathrm{Pb}-\mathrm{Zn}$ mineralization of the Triades area, Milos island, Greece. Bull. Geol. Soc. Greece 1998, 32, 137-144.

95. Cathelineau, M. Cation size occupancy in chlorites and illites as a function of temperature. Clay Miner. 1988, 23, 471-485. [CrossRef]

96. Fournier, R.O. The behaviour of silica in hydrothermal solutions. Geology and geochemistry of epithermal systems. Rev. Econ. Geol. 1985, 2, 45-61.

(C) 2018 by the authors. Licensee MDPI, Basel, Switzerland. This article is an open access article distributed under the terms and conditions of the Creative Commons Attribution (CC BY) license (http:/ / creativecommons.org/licenses/by/4.0/). 